\title{
ACTIVE SITES ENVIRONMENTAL MONITORING PROGRAM \\ FY 1992 ANNUAL REPORT
}

C. M. Morrissey, T. L. Ashwood, and D. S. Hicks

Environmental Sciences Division Publication No. 4002

Date Published: April 1994

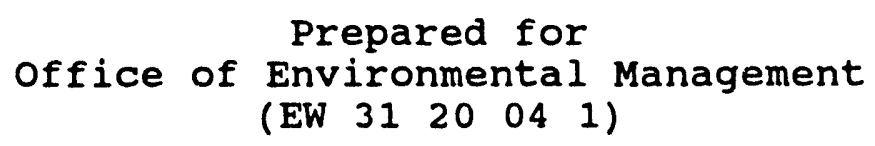

Prepared by the

OAK RIDGE NATIONAL LABORATORY

Oak Ridge, Tennessee 37831 managed by

MARTIN MARIETTA ENERGY SYSTEMS, INC.

$$
\text { for the }
$$

U.S. DEPARTMENT OF ENERGY

under contract DE-ACO5-84OR21400 


\section{CONTENTS}

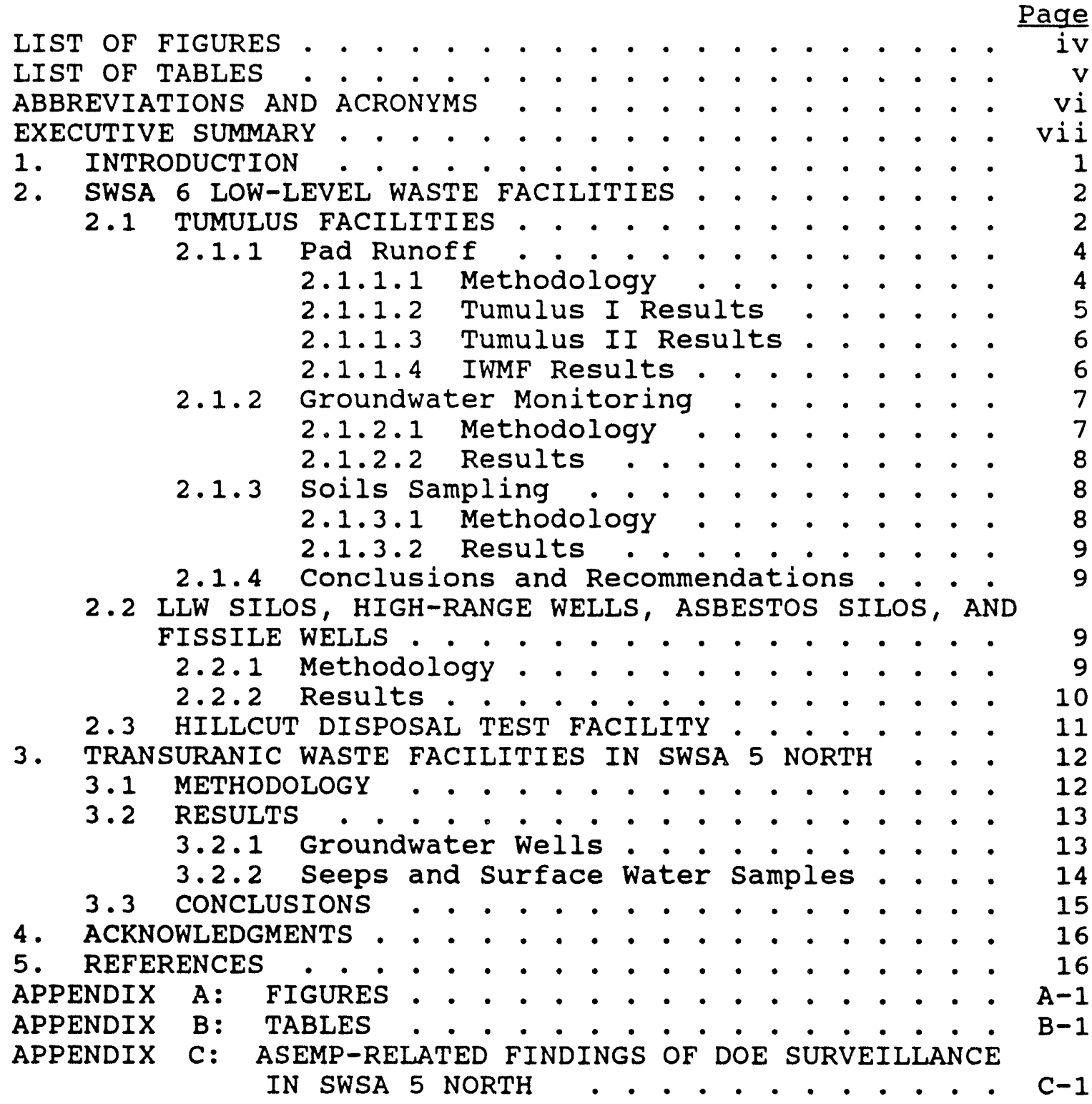




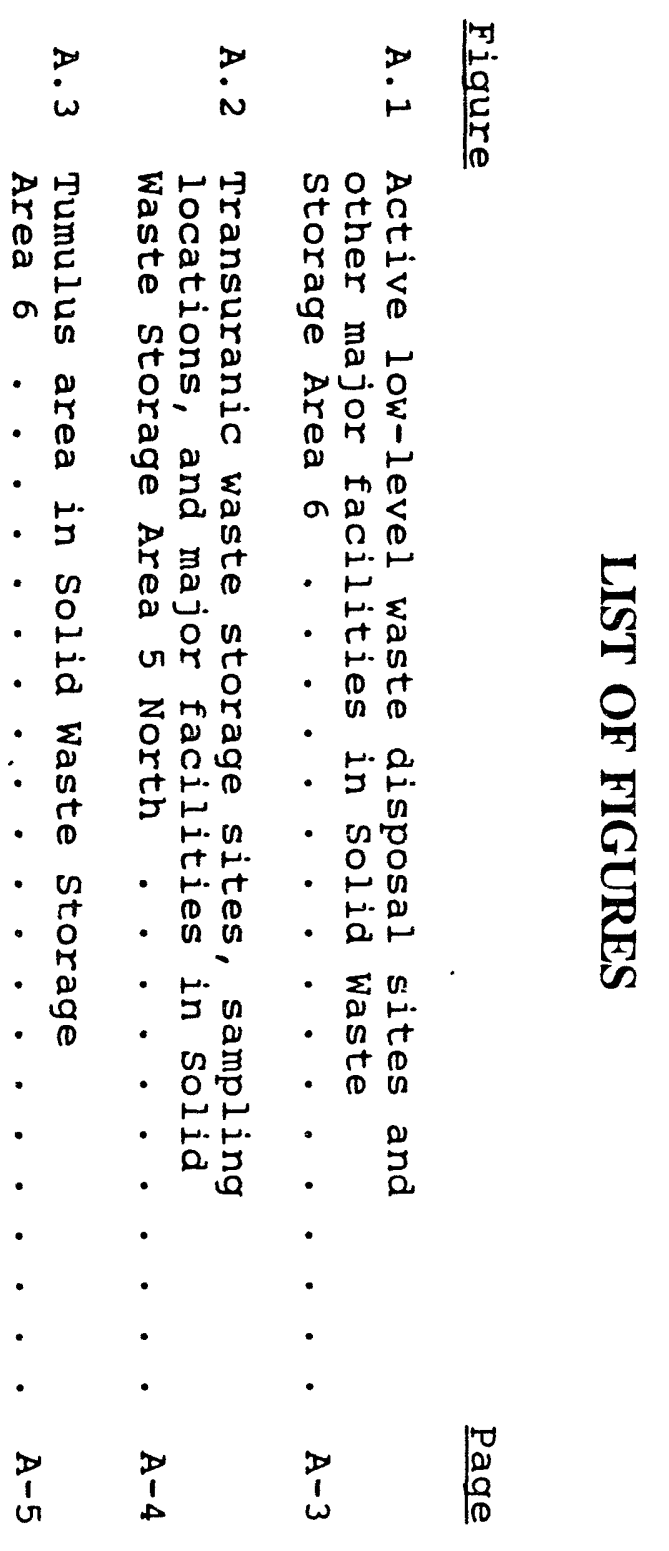




\section{LIST OF TABLES}

Table

Page

B.1 Field parameters and radionuclide concentrations in runoff from tumulus pads.. . . . . . . . B-3

B.2 Field parameters and radionuclide concentrations in tumulus underpad drainage . . . . . . . . B-4

B.3 Field parameters and radionuclide concentrations in IWMF pad water runoff . . . . . . . . . B-5

B. 4 Field parameters and radionuclide concentrations in tumulus area monitoring wells . . . . . . . B-7

B.5 Tumulus monitoring wells cation and anion data . B-9

B.6 Radionuclide concentrations in tumulus area soil samples... . . . . . . . . . . . . . . B-10

B.7 FY 1992 radionuclide data from intratrench wells near low-level waste silos in solid Waste storage

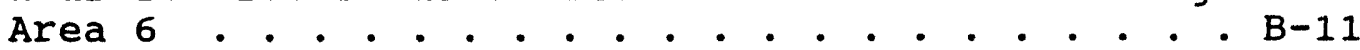

B.8 FY 1992 radionuclide data for water collected from wells next to high-range wells, asbestos silos, and fissile wells . . . . . . . . . B-17

B.9 Radionuclide concentrations in Solid Waste storage Area 5 North wells from November 1989 through July 1992

B.10 Radionuclide concentrations in Solid waste storage Area 5 North seeps and streams from March 1990 through July 1992 . . . . . . . . . . . . B-27 


$$
\text { viii }
$$




\section{ABBREVIATIONS AND ACRONYMS}

\begin{tabular}{|c|c|}
\hline$A C D$ & Analytical Chemistry Division \\
\hline ASEMP & Active sites Environmental Program \\
\hline DOE & U.S. Department of Energy \\
\hline ESD & Environmental Sciences Division \\
\hline FY & fiscal year \\
\hline HDTF & Hillcut Disposal Test Facility \\
\hline IT & intratrench \\
\hline IWMF & Interim Waste Management Facility \\
\hline LLW & low-level waste \\
\hline NPDES & National Pollutant Discharge Elimination system \\
\hline ORNL & Oak Ridge National Laboratory \\
\hline PWT & perched water table \\
\hline QA & quality assurance \\
\hline RCRA & Resource Conservation and Recovery Act \\
\hline swo & solid waste operations \\
\hline SWSA & Solid Waste Storage Area \\
\hline TMOI & Tumulus I \\
\hline TMOII & Tumulus II \\
\hline TOC & total organic carbon \\
\hline TRU & transuranic \\
\hline UND & underpad \\
\hline woc & White Oak Creek \\
\hline
\end{tabular}




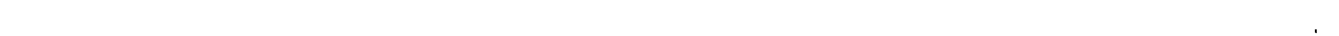

\section{.}




\section{EXECUTIVE SUMMARY}

This report summarizes the activities of the Active Sites Environmental Monitoring Program (ASEMP) from October 1991 through September 1992. Solid Waste Operations and the Environmental Sciences Division established ASEMP in 1989 to provide early detection and performance monitoring at active low-level waste (LLW) disposal sites in solid Waste Storage Area (SWSA) 6 and transuranic (TRU) waste storage sites in SWSA 5 as required by Chapter II and III of U.S. Department of Energy order 5820.2A.

The Interim Waste Managenment Facility (IWMF) began operation in December 1991. Monitoring results from the tumulus and IWMF disposal pads continue to indicate that no $L L W$ is leaching from the storage vaults. Storm water falling on the IWMF active pad was collected and transported to the Process Waste Treatment Plant while operators awaited approval of the National Pollutant Discharge Elimination system (NPDES) permit. Several of the recent samples collected from the active IWMF pad had $\mathrm{pH}$ levels above the NPDES limit of 9.0 because of alkali leached from the concrete. The increase in gross beta activity has been slight; only 1 of the 21 samples collected contained activity above the $5.0 \mathrm{~Bq} / \mathrm{L}$ action level.

Automated sample-collection and flow-measurement equipment has been installed at IWMF and is being tested. The flume designed to electronically measure flow from the IWMF pads and underpads is too large to be of practical value for measuring most flows at this site. Modification of this system will be necessary. A $\mathrm{CO}_{2}$ bubbler system designed to reduce the $\mathrm{pH}$ of water from the pads is being tested at IWMF.

A ${ }^{3} \mathrm{H}$ plume in the shallow groundwater in the tumulus area still exists. Tritium was observed during this reporting period in wells where it was not previously detected. A new plume of ${ }^{3} \mathrm{H}$ has apparently entered and is moving through the area.

Soil sampling in the tumulus area indicates that no contaminants have been released to the surrounding area during loading operations.

Three of the 44 intratrench (IT) wells around LLW silos accumulated water that contained levels of dissolved gross beta activity above the $5 \mathrm{~Bq} / \mathrm{L}$ action level during at least one sampling quarter. This was the first indication of elevated gross beta activity for two of these wells (wells 5 and 40). The third well (well 19) has exhibited elevated 
gross beta activity during all previous sampling periods. This gross beta activity is primarily of ${ }^{90} \mathrm{Sr}$, which probably leaches from the silos in the trench. All silos were grouted during the summer of 1992 in order to reduce the potential for waste migration. Evaluation of the effect of grouting for IT well 19 on the gross beta activity of the water has not yet been possible because of the insufficient accumulation of water for sampling. Dissolved gross beta activties in samples from backfill monitoring wells next to the high-range wells, asbestos silos, and fissile wells were below the $5 \mathrm{~Bq} / \mathrm{L}$ action level. Gross alpha activities in all IT wells and backfill monitoring wells were below the action level of $1 \mathrm{~Bq} / \mathrm{L}$.

Some of the IT wells have occasionally shown dissolved ${ }^{60} \mathrm{Co}$ or ${ }^{137} \mathrm{Cs}$ activities above the action levels of 1.5 and $2.5 \mathrm{~Bq} / \mathrm{L}$. These activities have generally been accompanied by large counting uncertainties because of the small sample volume. Sampling procedures were modified to collect larger volumes from wells that historically contain ${ }^{60} \mathrm{Co}$ and ${ }^{137} \mathrm{Cs}$ activities above action levels. Data from the new sampling method are being evaluated.

Much less water was collected from the Hillcut Disposal Test Facility (HDTF) during fiscal year (FY) 1992 than in the previous 2 years. This may indicate a leak in the padrunoff collection system. One sample of water was analyzed and contained no gross alpha, gross beta, or gamma-emitting isotope activities above action levels.

Groundwater and seep monitoring showed that the TRU contaminant plume from the burial trenches in the southwest corner of SWSA 5 North may be larger than previously reported. Groundwater monitoring in the SWSA 5 North area shows the continued presence in well 516 of ${ }^{241} \mathrm{Am}$ and ${ }^{244} \mathrm{Cm}$ concentrations above action levels. Measurable ${ }^{244} \mathrm{Cm}$ was observed for the first time in well 708, which is hydrologically downgradient from, and along strike with, the same group of burial trenches responsible for the ${ }^{244} \mathrm{~cm}$ contamination in well 516. Three other wells in the SWSA 5 North area showed low levels of ${ }^{241} \mathrm{Am}$ or ${ }^{244} \mathrm{Cm}$ during FY 1992 . 


\section{INTRODUCTION}

Chapter III of U.S. Department of Energy (DOE) order 5820.2A (DOE 1988) sets forth requirements for the management of the facilities in solid Waste storage Area (SWSA) 6 (Fig. A.1) that were used for the disposal of solid low-level (radioactive) waste (ILLW) on or after the date of the order (September 26, 1988). Chapter II of the order covers the transuranic (TRU) waste storage areas in SWSA 5 North (Fig. A.2). Both chapters require environmental monitoring to provide early warning of leaks before those leaks pose a threat to human health or the environment. chapter III also requires the monitoring of LLW disposal facilities so that thêir performance can be evaluated. In accordance with this order, the solid waste operations (SWO) Department at Oak Ridge National Laboratory (ORNL) has established an Active Sites Environmental Monitoring Program (ASEMP) that is implemented by staff of the Environmental Sciences Division (ESD) at ORNL.

This report presents the results of ASEMP activities for fiscal year (FY) 1992. The report is divided into two major areas: SWSA 6 [including tumulus pads, Interim Waste Management Facility (IWMF), and other sites] and TRU-waste storage facilities in SWSA 5 North. The monitoring methodology is described in the revised ASEMP program plan (Ashwood et al. 1992b). However, this report presents a summary of the methodology for each major area together with any changes that occurred during the report period. Figures and tables are grouped at the end of the report in Appendix $A$ and $B$, respectively.

During FY 1992, the program plan was revised to reflect changes in ASEMP approaches that have evolved over the first 2 years of operation (Ashwood et al. 1992b). The revised program plan includes documentation of the procedures used for specific ASEMP tasks. A revised program quality assurance (QA) plan was issued in draft form and serves as the basis for ASEMP activities. The SWSA 5 North activities of the program were scrutinized as part of a DOE audit. The audit findings related to ASEMP and the responses to them are included in Appendix $C$. The responsibility for monitoring of test casks associated with the Emergency Avoidance Solidification Campaign and the Liquid Waste Solidification Program was transferred from a subcontractor to ASEMP staff at the end of FY 1992. This new task requires further revision of the program plan. 


\section{SWSA 6 LOW-LEVEL WASTE FACILITIES}

SWSA 6 is currently the only operating LLW disposal facility on the Oak Ridge Reservation. Wastes that are certified free of liquids and hazardous wastes are further segregated into low- and high-activity wastes prior to disposal. Low-activity wastes are placed in concrete silos installed in trenches or in concrete vaults on concrete pads aboveground (called tumulus facilities) (Fig. A.1). Highactivity wastes are placed either in silos or in steellined, concrete-capped auger holes (called high-range wells), depending on the waste form and activity (Fig A.1). Asbestos waste that cannot be certified free of radioactive contamination is placed in concrete silos below ground. Fissile material is stored in steel-lined wells. During the mid-1980s, high-activity wastes were stored in concrete vaults (similar to tumulus vaults) placed on a concrete pad cut into the side of a hill as a demonstration of this method of disposal. This Hillcut Disposal Test Facility (HDTF) is not an active site, but it is included in ASEMP.

Monitoring activities associated with the SWSA 6 facilities are divided into three major areas: tumulus, including the IWMF; subsurface facilities; and HDTF. Tumulus monitoring activities include pad water monitoring as well as monitoring of water in the underpad area and in the aquitard below the pads. IWMF monitoring thus far includes only pad water. Monitoring at the subsurface facilities includes sampling of the perched water table that develops when shallow storm flow intercepts the silo trenches or the backfill surrounding the high-range wells, asbestos silos, and fissile wells. At HDTF, water that accumulates on the pad or in the underpad area is collected and sampled.

\subsection{TUMULUS FACILITIES}

The monitoring of water at the tumulus facilities, including IWMF, provides three levels of detection for. contaminant release. First, any release from the vaults to the pad surface would be detected in the pad water samples. second, any contaminants that might seep through the pads would be detected in the underpad water. Third, any contaminant release that passed through the pads and the underpads to the shallow groundwater would be detected in the wells in the area.

Tumulus I was covered by at least a temporary cover 
during the entire reporting period. Therefore, the surface of the Tumulus I pad collected little water. Tumulus II remained exposed to the weather while being loaded with vaults. When Tumulus II was fully loaded, tentlike structures covered both the Tumulus I and II pads. Since the completion of these covers in mid-January 1992, water has not accumulated on either pad. Prior to the installation of these semipermanent covers, the tumulus pad drains had been closed in response to concerns over the release of water with high $\mathrm{pH}$ and some gross beta and ${ }^{3} \mathrm{H}$ activity.

Water continues to drain from the underpads of both tumulus pads. This water flows through the monitoring shed and is released to west Tributary. The underpad drainage systems of the two pads are of different designs. Flow through the underpad of Tumulus II is expected, but a plastic liner that should prevent the accumulation of shallow groundwater lies under the Tumulus I underpad. The liner was designed to capture any water that might leak through the pad. Apparently, this lining system is not intact; shallow groundwater infiltrates the underpad collection system and drains to the monitoring shed.

IWMF became operational in December 1991. This facility is similar to the original tumulus pads. Currently, two concrete pads have been constructed. One pad is being loaded with waste-containing vaults, and the loading of waste onto the second pad will begin when the first pad is full. At least four more pads vill be constructed as needed.

As a result of concerns over the release of water from the concrete pads with a pH above the National Pollutant Discharge Elimination System (NPDES) permit limit, an automated $\mathrm{CO}_{2}$ bubbling system is being installed at IWMF. This system is designed to bubble $\mathrm{CO}_{2}$ into the active pad water when there is flow from the pad if the $\mathrm{pH}$ approaches the NPDES limit of 9.0 .

\subsubsection{Pad Runoff}

\subsubsection{Methodology}

The surface drains for all three tumulus facilities remained closed for this reporting period because of concerns over the high pH. Consequently, the pad surface water was sampled directly from the pads and was then pumped to a tanker and transported to the Process Waste Treatment plant. Samples of this water were analyzed for pH, specific conductance, gross alpha and beta activity, gamma-emitting 
radioisotopes, ${ }^{3} \mathrm{H}$, and total organic carbon (TOC). No samples have been collected from Tumulus I and II since midJanuary 1992 because of the installation of covers over both pads.

The underpad drains from Tumulus I and II continue to be sampled at least quarterly. Water that drains from these underpads flows to separate sumps in the tumulus monitoring shed. Grab samples are collected from the drain pipes that empty into the sumps. These samples are typically analyzed for $\mathrm{pH}$, specific conductance, and radionuclide activities.

The underpad drainage system at IWMF is similar in design to that at Tumulus II. When the IWMF monitoring system is fully operational, water infiltrating the underpads will be allowed to drain freely to the monitoring area. Little water is expected to accumulate under the pads because of an upgradient French drain. This French drain system was designed to divert shallow groundwater away from the pad area.

The monitoring area at IWMF consists of three sumps for the collection of water from the active pad, the inactive pad(s), and the underpads. The water collection system is designed to route water from all three sumps through an H-flume and then to the West Tributary through an NPDES sampling point. Electronic and mechanical equipment allows measurement of flow through the flume and collection of flow-proportional samples of the water being released. This automated monitoring and sampling equipment is not yet in use but is being tested and evaluated. The flume is much too large to measure the normal flow from the pads. Therefore, an alternative means of automating sample collection and monitoring flow is being developed.

\subsubsection{Tumulus I Results}

Although a temporary cover enclosed the Tumulus I pad, some water accumulated on the pad because of cover damage and partial removal of the cover during installation of the new tentlike cover. Ten samples of water were collected from the surface of the pad during this reporting period (Table B.1).

The $\mathrm{pH}$ of all ten samples was above the NPDES permitted release level of 9.0. Values for $\mathrm{pH}$ ranged from 9.17 to 10.88. Specific conductance values varied between 288 and $1751 \mu \mathrm{s} / \mathrm{cm}$. TOC data are variable and probably reflect algal growth on the pad.

No samples showed any statistically significant gross 
alpha, ${ }^{60} \mathrm{Co}$, or ${ }^{137} \mathrm{Cs}$ activity. Four samples contained gross beta activity at or above the action level of $5.0 \mathrm{~Bq} / \mathrm{L}$ (Ashwood and Ashwood 1991). Gross beta activity was generally much lower than during previous reporting periods. Previous samples showed that high concentrations of ${ }^{40} \mathrm{~K}$ are almost always associated with the elevated gross beta activity. However, only one sample (TMOI-452) collected during this period showed any ${ }^{40} \mathrm{~K}$ actvity $(7.0 \mathrm{~Bq} / \mathrm{L})$.

About half of the pad surface water samples displayed ${ }^{3} \mathrm{H}$ activity above background levels. This activity was generally lower than that observed during the previous reporting period. The source of this ${ }^{3} \mathrm{H}$ is still unknown.

Data for the Tumulus I underpad and construction base drain samples are reported in Table B.2. These data are incomplete, but they indicate slightly elevated levels of ${ }^{3} \mathrm{H}$ in both locations.

\subsubsection{Tumulus II Results}

Tumulus II remained uncovered until mid-January 1992. Nine samples of water accumulating on this pad were collected before the cover was installed. Data are reported in Table B.2. The $\mathrm{pH}$ in five of the samples exceeded 9.0 . Specific conductance values ranged from 104 to $387 \mu \mathrm{S} / \mathrm{cm}$ and are consistent with previously reported values. TOC values vary from 1.0 to 31 and probably reflect changes in algal growth on the pad. No samples were reported to have any statistically significant gross alpha, ${ }^{60} \mathrm{Co}$, or ${ }^{137} \mathrm{Cs}$ activity. Although most of the samples reflected slightly elevated gross beta activity, none of the reported activity exceeded the $5.0 \mathrm{~Bq} / \mathrm{L}$ action level. Tritium activity above background levels was observed in several of the pad water samples. This activity is variable and is much lower than that observed in the previous reporting period. During that period, a vault containing ${ }^{3} \mathrm{H}$ waste was discovered and moved away from most of the accumulating pad water. This vault remains on the pad and is probably a source of ${ }^{3} \mathrm{H}$. Data for the Tumulus II underpad water are reported in Table B.2. These data are incomplete but do show elevated ${ }^{3} \mathrm{H}$ activity. This activity may be the resujt of the ${ }^{3} \mathrm{H}$ groundwater plume in the tumulus area.

\subsubsection{ITMF Results}

Data for surface water from the IWMF pads are presented in Table B.3. Loading of the first pad began in December 1991. One hundred ninety-four vaults were on the pad at the end of September 1992. Twenty grab samples were collected from the active pad, and one was collected from the empty 
pad.

The $\mathrm{pH}$ has been variable but has shown a generally upward trend as more vaults are loaded onto the pad; four samples have exceeded 9.0. Specific conductance has also generally increased with the loading of the pad. A sample collected from the empty pad had a pH of 8.4 and a specific conductance of only $81 \mu \mathrm{S} / \mathrm{cm}$. TOC concentrations in the active pad water range from 1.1 to $30 \mathrm{mg} / \mathrm{L}$.

One pad water sample (IWMF-026) and two blank samples (IWMF-011 and -025) were reported by the Analytical Chemistry Division (ACD) of ORNL to have gross alpha activities greater than zero but below the first action level of $1.0 \mathrm{~Bq} / \mathrm{L}$. Gross beta activity has shown the same generally increasing trend as that previously observed for the tumulus pads (Ashwood et al. 1991; Wickliff et al. $1991 a, b)$. However, only one sample (IWMF-030) was above the $5.0 \mathrm{~Bq} / \mathrm{L}$ first action level. One sample (IWMF-018) exhibited both ${ }^{60} \mathrm{Co}$ and ${ }^{137} \mathrm{Cs}$ activities $>0$. $A C D$ reported that other pad water samples (IWMF-028 and 038) had ${ }^{137} \mathrm{Cs}$ activities $>0$. ACD also reported ${ }^{137} \mathrm{Cs}$ activity $>0$ in two blanks (IWMF-025 and 039). The highest activity value for any of these samples was $1.1 \mathrm{~Bq} / \mathrm{L}$, well below the action level.

Most of the ${ }^{3} \mathrm{H}$ values in the IWMF pad water are very low and probably reflect atmospheric levels. However, at least one of the samples (IWMF-024) appears to have a somewhat elevated ${ }^{3} \mathrm{H}$ activity of $370 \mathrm{~Bq} / \mathrm{L}$.

Water has not been allowed to drain from the IWMF underpad. This underpad system is expected to contain very little water because of the influence of the French drain.

\subsubsection{Groundwater Monitoring}

\subsubsection{Methodology}

Twelve wells designed to monitor the shallow groundwater in the area encircle the tumulus pads (Fig. A.3.). These wells were drilled to auger refusal (typically 20 to $30 \mathrm{ft.}$ ) and are screened to include as much of the zone of permanent groundwater above bedrock as possible (Wickliff et al. 1991b: Appendix C). Eleven of the wells are equipped with dedicated sampling pumps and are sampled quarterly for radiological and field parameters. Well 381 is not included in the sampling program because it was not drilled as part of the tumulus program and is of uncertain constriction. Field parameters are measured with the use of a Hydrolab equipped with a flow-through cell. Six of the 11 
wells are randomly selected for annual sampling and analysis for cations, anions, TOC, and volatile and semivolatile organics.

\subsubsection{Results}

Analytical results from four rounds of quarterly sampling are presented in Table B.4. Field parameters are very consistent from one sampling period to the next and are within ranges normally encountered in the tumulus area (Ashwood et al. 1991; Wickliff et al. 1991b; Solomon et al. 1988).

All radionuclide activities in the tumulus area groundwater are below action levels. Tritium is the only radionuclide detected in any of the monitoring wells. This ${ }^{3} \mathrm{H}$ plume has been observed for the past several years and was previously detected mainly in wells 1036 and 1039 (Ashwood et al. 1991; Wickliff et al. 1991a,b). However, during this reporting period, increased ${ }^{3} \mathrm{H}$ activity was observed in wells $1037,1038,1258$, and 1259. Activity in well 1036 increased and then stabilized. Activity in 1039 decreased early in this period and then increased again. These data indicate that the plume is spreading to the southwest and that there is possibly a new ${ }^{3} \mathrm{H}$ source east of the tumulus pads.

Cation and anion data for the monitoring wells are reported in Table B.5. These data are similar to previously reported data (Wickliff et al. 1991b) and contain no unexpected or unusual results.

\subsection{3 soils sampling}

\subsubsection{Methodology}

Samples of surface soil around the tumulus pads are collected to detect any activity released during loading operations. Twelve samples were collected near each monitoring well in the tumulus area and submitted for gross alpha and beta analysis and a gamma scan.

\subsubsection{Results}

Table B. 6 reports the results of soil sampling during FY 1992. The large counting errors associated with the gross alpha and gross beta analyses make interpretation of these data difficult. Potassium-40 activity is consistent with previously reported data for soil in the tumulus area (Yager et al. 1989). One sample (1257) showed a low level of ${ }^{60} \mathrm{Co}$ activity. Seven of the 12 samples showed levels of 
${ }^{137} \mathrm{Cs}$ that were significantly $>0$.

\section{1 .4 Conclusions}

Tumulus facilities continue to contain the LLW placed within them. As in previous years, the only anomalies noted in the pad water analyses are the high $\mathrm{pH}$ and elevated level of gross beta activity. Both of these parameters have increased as more vaults have been loaded onto the pads. The relevance of these two parameters in relation to the long-term integrity of the tumulus facilities is still not clear. At IWMF, a more detailed investigation of the chemistry of pad water will be conducted in FY 1993 in an effort to understand whether pad water chemistry provides any indication of vault integrity.

Tritium activity in groundwater in the tumulus area continues to be present and has appeared in wells where it was not previously detected. The source(s) of this ${ }^{3} \mathrm{H}$ are not certain. Originally, the effluent from the French drain in the 49-trench area was suspected to be the source. However, 2 years ago the effluent pipe was relocated, and no reduction in ${ }^{3} \mathrm{H}$ activity in tumulus area groundwater has occurred. It is unlikely that the loss of ${ }^{3} \mathrm{H}$ from tumulus vaults has had any effect on this plume.

\subsection{ILW SILOS, HIGH-RANGE WELLS, ASBESTOS SILOS, AND FISSILE WELLS}

LLW silos in SWSA 6 are generally installed in groups of four within a trench. The relatively high permeability of the backfilled soil can cause an intermittent perched water table as a result of subsurface storm flow. Davis et al. (1989) demonstrated that some of the LLW silos within trenches leak. Therefore, to provide early contaminant detection, 2-in. drive-point monitoring wells with 5-ft screened sections were installed in May 1990 in trenches that previously had no monitoring wells. These wells provide a way to monitor groups of silos for containment failure, leaching of wastes, and contaminant transport. Drive-point wells were also installed in May 1990 in the backfilled soil next to high-range wells, asbestos silos, and fissile wells.

\subsubsection{Methodology}

The intratrench (IT) wells and backfill monitoring wells are equipped with a weighted sample bottle. Samples are collected quarterly from those wells with sufficient water (usually 100 to $250 \mathrm{~mL}$ ) and are prepared for analyses 
by forcing the sample through a $0.45-\mu \mathrm{m}$ filter and acidifying the sample to $\mathrm{pH}<2$ with $\mathrm{HNO}_{3}$. Filters are counted for gamma-emitting isotopes in ESD. ACD analyzes the water samples for gross alpha and gross beta activities and for gamma-emitting isotopes.

\subsubsection{Results}

The FY 1992 quarterly sampling of IT wells around LLW silos and of wells next to high-range wells (identified as AUG), asbestos silos (C520 and C595), and fissile wells (FIS102 and FIS?) was completed in December 1991 and in March, June, and September 1992. Samples were collected from most of the 44 IT wells around LLW silos, from both wells next to the two asbestos silos, and from both wells next to the two fissile wells. Samples were also collected from eight of the nine wells in the high-range well area.

Gross alpha and g::oss beta activities in the well samples were below the action levels of 1 and $5 \mathrm{~Bq} / \mathrm{L}$, respectively, with the exception of gross beta activities in IT wells 5, 19, and 40 (Tables B.7 and B.8). Activities in the third-quarter samples from IT wells 5 and 40 were the first occurrence of gross beta activities above the action level in these two wells. During the fourth quarter, the gross beta activity in IT well 40 returned to a level below the action level. Analyses of the sample from IT well 5 from the fourth-quarter sampling are not complete. Samples from IT well 19 consistently contain elevated gross beta activities, primarily ${ }^{90} \mathrm{Sr}$, which probably are a result of leaching from waste in one or more of the silos in the trench (Ashwood et al. 1991, 1992a; Wickliff et al. 1991b). This trench is not an active site under the definition in DOE order 5820.2A. The silos within the trench were installed with the use of precast concrete drainage pipes obtained from the Clinch River Breeder Reactor Project, and the wastes within the silos were not originally grouted. However, in July 1992 the silos were grouted as part of a measure to reduce the potential for release of radionuclides from the LLW silos. Evaluation of the effectiveness of the grouting effort could not be made because IT Well 19 did not contain sufficient water for sample collection during the third and fourth quarters.

Most of the filtered samples from IT wells and backfill monitoring wells contained ${ }^{137} \mathrm{Cs}$ and ${ }^{60} \mathrm{Co}$ activities below the action levels of 2.5 and $1.5 \mathrm{~Bq} / \mathrm{L}$, respectively (Tables $\mathrm{B} .7$ and $\mathrm{B} .8)$. However, some ${ }^{137} \mathrm{Cs}$ and ${ }^{60} \mathrm{Co}$ results had associated uncertainties that were greater than the action levels. The large associated uncertainties primarily result from a limited sample volume (i.e., limited to the volume of the 
weighted bottle and to the amount of water perched within the trench). Therefore, during the last quarter, sampling methods were modified for those wells that contained ${ }^{60}$ co and/or ${ }^{137} \mathrm{Cs}$ activities above the action levels during the past 2 years. These wells were monitored approximately twice a month and will continue to be monitored until a 1-L composite sample can be collected. IT wells 35 and 36 , for example, had ${ }^{60} \mathrm{Co}$ values of $0.4 \pm 0.6$ and $1.4 \pm 0.6 \mathrm{Bg} / \mathrm{L}$, respectively, during the third quarter of FY 1992 and values of $0.17 \pm 0.1$ and $-0.01 \pm 0.1 \mathrm{~Bq} / \mathrm{L}$, respectively, during the fourth quarter, when a $1-\mathrm{L}$ composite sample was collected and analyzed (Table B.7). To effectively determine the presence of trace amounts of contaminants, the sampling procedure may need to be modified for all of the wells.

Although a ${ }^{137} \mathrm{Cs}$ activity above the action level was found in only one filtered sample (IT Well 5), 23 wells had measurable ${ }^{137} \mathrm{Cs}$ activity associated with the particulates retained on the filters (Tables B.7 and B. 8 ). Counting the filters for gamma-emitting radionuclides appears to be an effective method for detecting low levels of contaminants (particularly ${ }^{137} \mathrm{Cs}$ because of its particle-reactive properties). However, the quarterly samples contain variable amounts of sediment. Only two samples (IT Well 13 and AUG 48) contained the combined activity of particulate${ }^{137} \mathrm{Cs}$ and dissolved $-{ }^{137} \mathrm{Cs}$ that exceeded the $2.5 \mathrm{~Bq} / \mathrm{L}$ action level originally set for the water samples. An action level for particulate-associated ${ }^{137} \mathrm{Cs}$ or ${ }^{60} \mathrm{Co}$ has not been established. The activities of particulate ${ }^{137} \mathrm{Cs}$ appear to be decreasing in IT well 13 and increasing in AUG 48 (next to a high-range well), but these trends are tentative.

\subsection{HILLCUT DISPOSAL TEST FACIIITY}

Runoff from the pad is collected in an above-grade tank (tank No. 1) at the HDTF. The volume of pad runoff was measured weekly during FY 1992. Only one pad runoff sample was collected from tank No. 1 when the tank was near its maximum capacity in March 1992. After the sample was collected, the contents of tank No. 1 were transferred to a holding tank until radionuclide analyses were completed. Gross alpha, gross beta, and gamma-emitting isotope activities were below the action levels. Approximately 3300 $L$ of pad runoff was collected in FY 1992. This is only onethird of the volume collected during the previous 2 years and may indicate a leak in the tank or draining system.

Runoff from the underpad gravel drain is collected in an above-grade tank. A 2-in. flexible hose diverts any groundwater runoff to a holding tank. As in previous vears 
very little if any runoff occurred from the underpad gravel during FY 1992 .

Two wells at HDTF were monitored weekly during the period. The well in the gravel layer around the pad remained dry. The weekly water levels in the well on the pad remained fairly constant, and they indicate that a small amount of standing water (depth $\leq 0.5 \mathrm{in.}$ ) remained on the pad except during october 1991 and September 1992.

\section{TRU WASTE FACILITIES IN SWSA 5 NORTH}

TRU wastes have been stored in SWSA 5 North since 1970 (Shoun 1987). Wastes are stored in a variety of facilities, from unlined trenches to subsurface concrete vaults. Groundwater well 516, immediately downgradient from a group of TRU waste trenches (Fig. A.2), contains gross alpha activity varying from 30 to $150 \mathrm{~Bq} / \mathrm{L}$ (Ashwood et al. 1990, 1991, 1992a; Wickliff et al. 1991a,b). Curium-244 is the dominant radionuclide, and traces of ${ }^{241}$ Am have been reported from separate samples. The TRU waste trenches also contain some elemental lead (Stewart et al. 1989). Samples from well 516 do not contain detectable concentrations of volatile organics (Wickliff et al. 1991b), and metal concentrations are below regulatory concern (Ashwood et al. 1991). The trenches are upgradient from White oak creek (WOC), which drains most of ORNL and eventually enters the Clinch River. Curium-244 and ${ }^{241} \mathrm{Am}$ have been detected in two seeps (Fig. A.2: WOC 213 and WOC 255) in the bank of WOC (Ashwood et al. 1991). These seeps are along geologic strike from the trenches.

\subsection{METHODOLOGY}

Fifteen groundwater wells surrounding the TRU-waste storage facilities are sampled quarterly (Ashwood et al. 1992b). Samples are collected after the wells are purged. All samples are filtered through $0.45-\mu \mathrm{m}$ filters and then acidified to a $\mathrm{pH}<2$ with $\mathrm{HNO}_{3}$. Prior to october 1990, however, samples were acidified but not filtered. Analytes include gross alpha, gross beta, ${ }^{60} \mathrm{Co},{ }^{137} \mathrm{Cs},{ }^{241} \mathrm{Am}$, and ${ }^{244} \mathrm{Cm}$. Beginning in FY $1992,{ }^{3} \mathrm{H}$ analysis was limited to one quarterly sample because ${ }^{3} \mathrm{H}$ is not a contaminant of concern for this site and the ${ }^{3} \mathrm{H}$ data have not provided any insight into the transport of TRU contaminants.

Six seep and two stream locations are sampled quarterly (Ashwood et al. 1992b). Seeps identified as WOC XXX (Fig. 
A.2) are located in the bank of Woc; however, only four of those seeps (WOC 160, WOC 175, WOC 213, and WOC 255) are sampled regularly. The remaining two seeps are between SWSA 5 North and WOC. Seep and stream samples are analyzed for the same set of parameters as well samples are, except that seep or stream samples were not analyzed for ${ }^{3} \mathrm{H}$ in FY 1992.

Action levels have been established for gross beta ( 2 $\mathrm{Bq} / \mathrm{L}),{ }^{60} \mathrm{Co}(1.5 \mathrm{~Bq} / \mathrm{L})$, and ${ }^{137} \mathrm{Cs}$ ( $1 \mathrm{~Bq} / \mathrm{L}$ ) (Ashwood and Ashwood 1991). An action level was not established for gross alpha because gross alpha is not a reliable indicator of TRU contamination at trace levels. Instead, concentrations of ${ }^{241} \mathrm{Am}$ or ${ }^{244} \mathrm{Cm}$ that exceed the associated counting error by a factor of 2 are flagged as potentially contaminated samples. This approach roughly corresponds to a $5 \%$ probability that a sample would be flagged as contaminated when it is not.

\subsection{RESULTS}

\subsubsection{Groundwater Fells}

Samples were obtained from all wells except well 516 in all four quarters of FY 1992. Because of problems with the pump, well 516 could not be sampled in the second quarter. The third-quarter sampling began in late May and continued into early July because of conflicts between ASEMP sample collection and sample collection by the subcontractor supporting the Environmental Restoration program. Because of miscommunication with the analytical lab, analyses for ${ }^{241} \mathrm{Am}$ and ${ }^{244} \mathrm{~cm}$ were not performed on the second-quarter samples. Results of the fourth-quarter sampling are not expected to be available before the deadline for this report. In future years, fourth-quarter samples will be collected in early August so that results will be available for the annual report. This approach could not be used in FY 1992 because of the length of time required for the third-quarter sampling.

Well 516 continues to contain ${ }^{241} \mathrm{Am}$ and ${ }^{244} \mathrm{~cm}$ concentrations above the action level (Table B.9), but gross beta concentrations were below the action level for the first time since the beginning of the program in FY 1990 (Table B.9).

Wells 519 and 524 contained low but statistically significant levels of ${ }^{241} \mathrm{Am}$ during the third-quarter sampling (Table B.9). Well 716 has contained ${ }^{241} \mathrm{Am}$ and ${ }^{244} \mathrm{Cm}$ above the action level in two of the past three periods reported. None of these wells has a history of gross alpha or ${ }^{241} \mathrm{Am}$ 
contamination, and the reported values are low enough $(<0.1$ $\mathrm{Bq} / \mathrm{L}$ ) that they may represent a statistical anomaly.

Well 521 has contained significant ${ }^{241} \mathrm{Am}$ or ${ }^{244} \mathrm{Cm}$ in each of the past three periods reported here (Table B.9). Moreover, the value reported in August $1991(0.3 \pm 0.09$ $\mathrm{Bq} / \mathrm{L}$ ) is too high to be considered a statistical anomaly. This well is near a group of trenches in the northeast corner of SWSA 5 North (Fig. A.2).

Well 708 has contained measurable ${ }^{244} \mathrm{Cm}$ throughout FY 1992 , though samples from preseding years did not contain appreciable concentrations of this radionuclide (Table B.9). Well 708 is hydrologically downgradient from and along strike with the same group of burial trenches responsible for the ${ }^{244} \mathrm{Cm}$ contamination in well 516 (Fig. A.2).

No significant gamma-emitting contamination was measured in any wells.

\subsubsection{Seeps and surface water samples}

Seep and stream samples were collected during all quarters of FY 1992. The seep at WOC 213 did not have sufficient flow for sampling during any of the periods. Seep 5NW 01 was not sampled during the second, third, and fourth quarters because of insufficient flow. The WOC 175 seep was not sampled during the third and fourth quarters because of insufficient flow. The third-quarter sampling was not conducted until late July, and the fourth-quarter sampling was not conducted until october. Fourth-quarter results are not available for this report.

Stream location 5NNT 01 contained ${ }^{241} \mathrm{Am}$ or ${ }^{244} \mathrm{Cm}$ contamination at low but reportable levels throughout $F Y$ 1992 (Table B.10). Samples from previous years were not analyzed for specific alpha-emitting isotopes, so no history of contamination is available. Neither of the wells upgradient of this seep (522 and 523) shows gross alpha or TRU contamination.

Stream location 5NST 02 has a history of high gross alpha and gross beta contamination (Table B.10). Samples collected since early FY 1991 demonstrate that the alpha contamination is not caused by TRU isotopes (Table B.10).

The reportable concentration of ${ }^{244} \mathrm{Cm}$ in seep $5 \mathrm{NW} 01$ during the first quarter is low enough to be a statistical anomaly (Tabl B.10), but further samples from this site are needed to cc..firm this hypothesis. Furthermore, it should be noted that this seep is along strike with the burial 
trenches and the contaminated bank seeps at woC 255 (Fig. A.2).

The seep at woc 255 has contained reportable concentrations of ${ }^{244} \mathrm{~cm}$ since analysis for this isotope began in the second quarter of FY 1991 (Table B.10).

No significant gamma-emitting contamination was measured in any seeps.

\subsection{CONCLUSIONS}

The TRU contaminant plume from the burial trenches in the southwest corner of SWSA 5 North (Fig. A.2) apparently is larger than previously reported. Identification of TRU isotopes in wells 708 and 716 and seep 5NW 01 suggests that the plume is broad enough to encompass these three

locations. The blips of ${ }^{241} \mathrm{Am}$ measured sporadically in well 513 and seep 5NW 02 may even indicate that the plume may reach these sites under certain hydrologic conditions.

Well 524, and perhaps well 521, is downgradient from the burial trenches in the northeast corner of SWSA 5 North (Fig. A.2). The sporadic TRU contamination seen in these wells may therefore indicate that material is leaching from these trenches. The contamination seen in stream location 5NNT 01 may also originate from these trenches, although the hydrologic connection is somewhat tenuous.

\section{ACKNOWLEDGMENTS}

The authors wish to thank Dave Hall and Harold Adair of the Waste Management and Remedial Action Division for guidance and support. Della Marshall, Tony Thomas, scott Gregory, and Lauren Larsen of the Environmental Sciences Division provided valuable assistance in sampling and analysis of the data. Jeff Riggs and Roy Freeman of the Instrumentation and Controls Division have consistently supplied excellent guidance and craftsmanship in the design, operation, and maintenance of the electronic monitoring and sampling equipment. 


\section{REFERENCES}

Ashwood, J. S., and T. L. Ashwood. 1991. Active sites environmental monitoring program: Action levels. ORNL/M-1569. Oak Ridge National Laboratory.

Ashwood, T. L., D. S. Wickliff, C. M. Morrissey, and H. L. Adair. 1990. Active sites monitoring at Oak Ridge National Laboratory. pp. 397-399 In Proceedings of SPECTRUM 90 Nuclear and Hazardous Waste Management International Topical Meeting, September 30-October 4, 1990, Knoxville, Tennessee. American Nuclear Society, La Grange Park, Illinois.

Ashwood, T. I., D. S. Wickliff, and C. M. Morrissey. 1991. Active sites environmental monitoring program: Mid-FY 1991 Report. ORNL/M-1442. Oak Ridge National Laboratory.

Ashwood, T. L., D. S. Wickliff, and C. M. Morrissey. 1992 . Active sites environmental monitoring program: FY 1991 annual report. ORNL/M-1792. Oak Ridge National Laboratory.

Ashwood, T. L., D. S. Wickliff, and C. M. Morrissey. 1992b. Active sites environmental monitoring program: program plan Rev. 1. ORNL/M-1793. Oak Ridge National Laboratory.

Davis, E. C., C. W. Francis, and R. J. Luxmoore. 1989. An evaluation of water leakage into concrete low-level radioactive waste disposal silos at ORNL's Solid Waste Storage Area 6. ORNL/TM-11164. Oak Ridge National Laboratory.

Shoun, R. R. 1987. Environmental data package for ORNL Waste Area Grouping-Five (WAG-5), Solid Waste Storage Area-Five (SWSA-5). ORNL/RAP-19. Oak Ridge National Laboratory.

Solomon, D. K., R. C. Haese, T. V. Dinsmore, and A. D. Kelmers. 1988. Sampling and analysis of SWSA 6 trench leachates and groundwaters. ORNL/TM-10813. Oak Ridge National Laboratory.

stewart, R. C., L. S. Dickerson, S. F. Joost, and D. C. Osucha. 1989. Remote-handled transuranic solid waste characterization study: Oak Ridge National Laboratory. ORNL/TM-11050. Oak Ridge National Laboratory.

U.S. Department of Energy (DOE). 1988. Radioactive waste management. DOE order 5820.2A, September 26, 1988.

Washington, D.C. 
Wickliff, D. S., C. M. Morrissey, and T. L. Ashwood. 1991a. Active sites environmental monitoring program: Mid-FY 1990 summary report. ORNL/M-1179. Oak Ridge National Laboratory.

Wickliff, D. S., C. M. Morrissey, and T. L. Ashwood. 1991b. Active sites environmental monitoring program: FY 1990 annual report. ORNL/M-1327. Oak Ridge National Laboratory.

Yager, R. E., J. A. Furnari, and P. M. Craig. 1989. Environmental monitoring six-month report for the tumulus disposal demonstration project: Mid-fiscal year 1989. ORNL/Sub/89-SC924/2. Oak Ridge National Laboratory. 


\section{APPENDIX A: FIGURES}




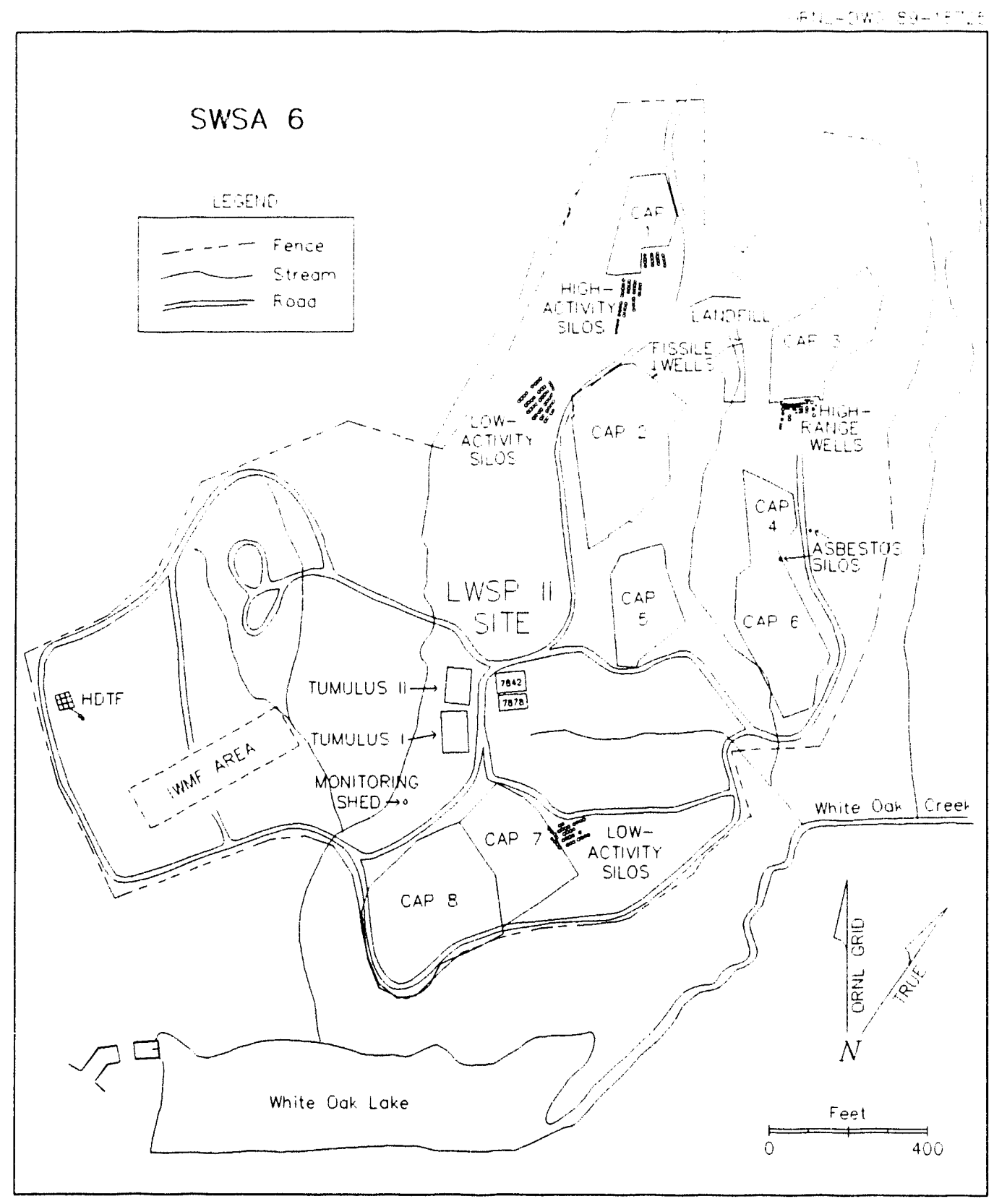

Figure A.1. Active low-level waste disposal sites and other major facilities in Solid Waste storage Area 6. 


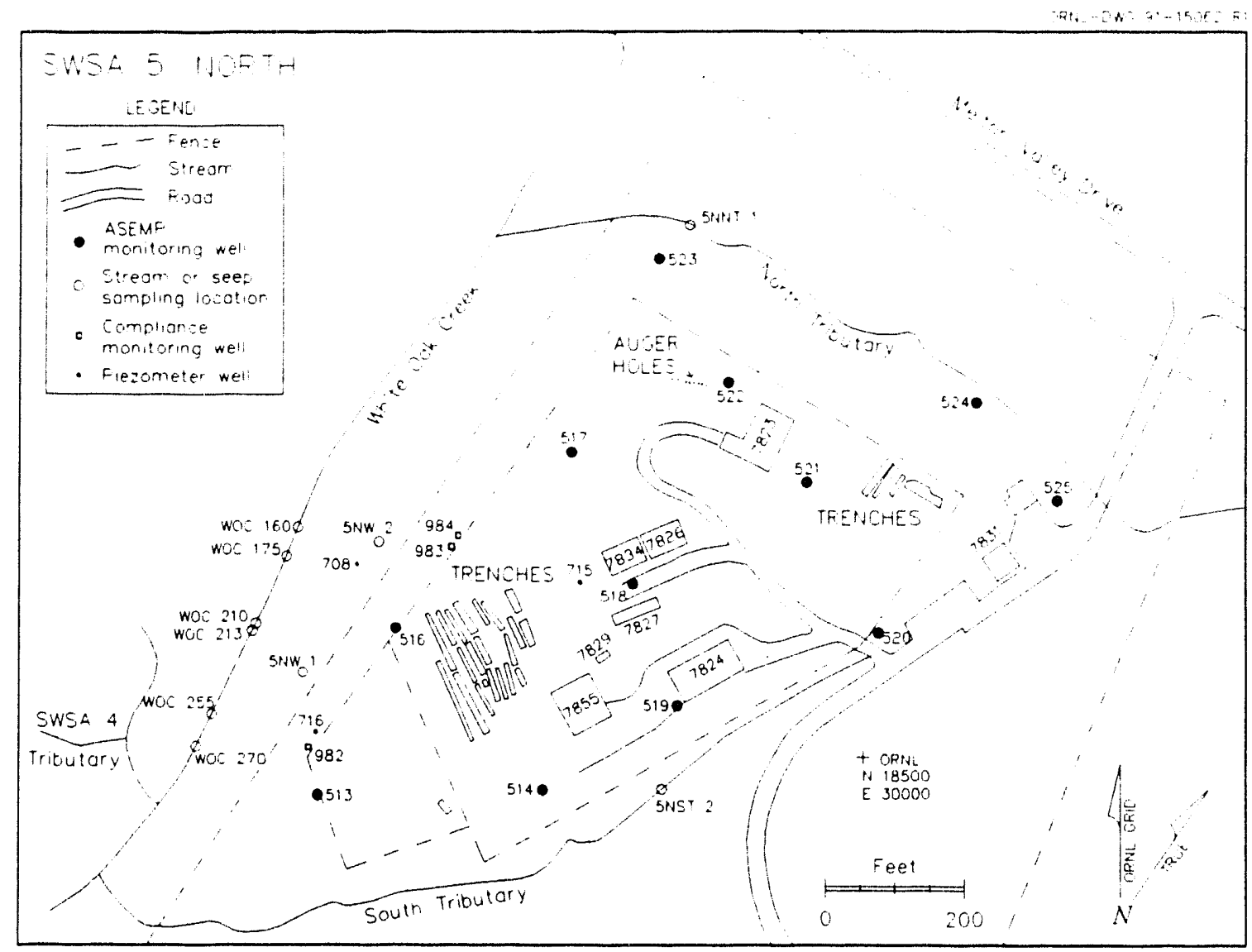

Figure A.2. Transuranic waste storage sites, sampling locations, and major facilities in solid Waste storage Area 5 North. 


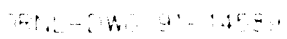

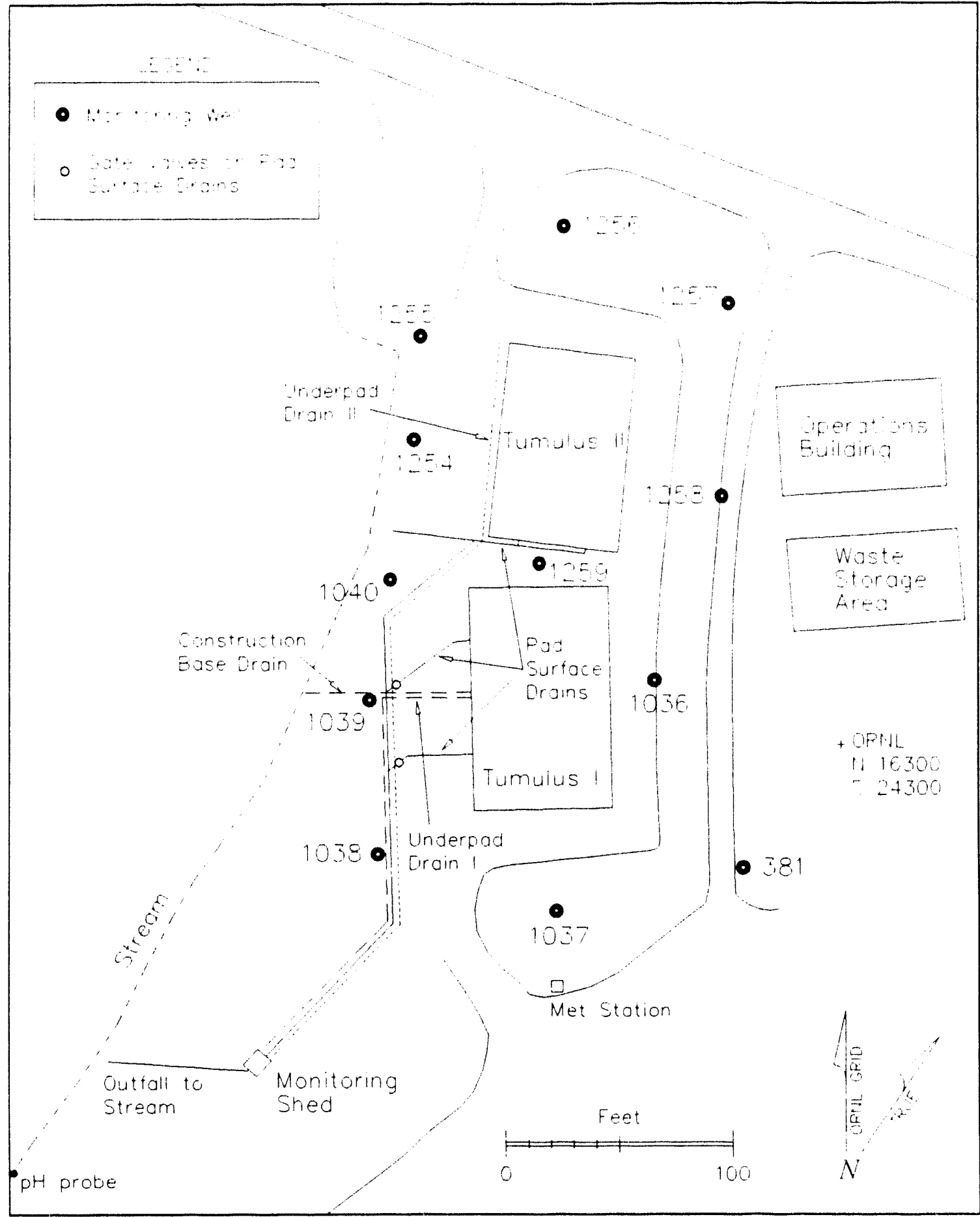

Figure A.3. Tumulus area in Solid Waste Storage Area 6. 


\section{APPENDIX B: TABLES}


Table B.1. Field parameters and radionuclide concentrations in runoff from tumulus pads"

\begin{tabular}{|c|c|c|c|c|c|c|c|c|c|c|c|c|c|c|}
\hline Sample & Date & $\mathrm{pH}$ & $\begin{array}{c}\text { Specific } \\
\text { conductance }\end{array}$ & Gross A & Alpha & Gross B & eta & ${ }^{60} \mathrm{Co}$ & & ${ }^{137} \mathrm{Cs}$ & & ${ }^{3} \mathrm{H}$ & & TOC $^{c}$ \\
\hline \multicolumn{15}{|c|}{ Tumulus I pad water: } \\
\hline TMOI-452 & $10 / 16 / 91$ & 10.88 & 758 & $0.065 \pm$ & 0.03 & $6.3 \pm$ & 0.3 & $-0.01 \pm$ & 0.06 & $0.06 \pm$ & 0.09 & $250 \pm$ & 20 & 43 \\
\hline TMOI-454 & $11 / 06 / 91$ & 10.48 & 1582 & $-0.41 \pm$ & 0.06 & $14 \pm$ & 2 & $0.03 \pm$ & 0.04 & $0.01 \pm$ & 0.08 & $-12 \pm$ & 10 & 9.1 \\
\hline TMOI-456 & $11 / 11 / 91$ & 10.29 & 1751 & $0.10 \pm$ & 0.05 & $10 \pm$ & 1 & $0.05 \pm$ & 0.06 & $0.12 \pm$ & 0.12 & $1700 \pm$ & 50 & 15 \\
\hline TMOI-458 & $11 / 21 / 91$ & 10.26 & 42 & $0.018 \pm$ & 0.023 & $0.48 \pm$ & 0.0 & $-0.05 \pm$ & 0.05 & $-0.06 \pm$ & 0.09 & $120 \pm$ & 15 & 15.3 \\
\hline TMOI-460 & $12 / 02 / 91$ & 9.72 & 288 & $0.002 \pm$ & 0.018 & $1.2 \pm$ & 0.1 & $-0.16 \pm$ & 0.15 & $0.37 \pm$ & 0.17 & $240 \pm$ & 25 & 7.6 \\
\hline TMOI-462 & $12 / 11 / 91$ & 9.58 & 312 & $0.041 \pm$ & 0.02 & $-0.07 \pm$ & 0.20 & $0.09 \pm$ & 0.05 & $0.12 \pm$ & 0.12 & $690 \pm$ & 25 & 5.6 \\
\hline TMOI-464 & $12 / 23 / 91$ & 9.80 & 667 & $0.06 \pm$ & 0.07 & $5.0 \pm$ & 0.5 & $0.02 \pm$ & 0.08 & $-0.01 \pm$ & 0.10 & $620 \pm$ & 25 & 8.1 \\
\hline TMOI-466 & $12 / 30 / 91$ & 9.38 & 466 & $0.12 \pm$ & 0.07 & $4.2 \pm$ & 0.3 & $0.02 \pm$ & 0.04 & $0.04 \pm$ & 0.07 & $520 \pm$ & 25 & 6.8 \\
\hline TMOI-468 & $01 / 03 / 92$ & 10.35 & 302 & $0.09 \pm$ & 0.06 & $2.0 \pm$ & 0.3 & $-0.19 \pm$ & 0.11 & $-0.03 \pm$ & 0.16 & $40 \pm$ & 22 & 9.5 \\
\hline TMOI-470 & $01 / 13 / 92$ & 9.17 & 721 & $0.1 \pm$ & 0.0 & $4.2 \pm$ & 0.2 & $0.07 \pm$ & 0.05 & $-0.04 \pm$ & 0.11 & $900 \pm$ & 25 & 10 \\
\hline \multicolumn{15}{|c|}{ Tumulus II pad water: } \\
\hline TMOII-114 & $10 / 16 / 91$ & 9.15 & 212 & $0.074 \pm$ & 0.03 & $1.2 \pm$ & 0.1 & $0.01 \pm$ & 0.01 & $0.03 \pm$ & 0.10 & $770 \pm$ & 11 & 6.7 \\
\hline TMOII-116 & $11 / 06 / 91$ & 9.12 & 277 & $0.13 \pm$ & 0.07 & $2.4 \pm$ & 0.2 & $-0.01 \pm$ & 0.04 & $0.03 \pm$ & 0.07 & $-6 \pm$ & 50 & 25 \\
\hline TMOII-118 & $11 / 11 / 91$ & 9.24 & 387 & $0.007 \pm$ & 0.021 & $2.5 \pm$ & 0.2 & $-0.04 \pm$ & 0.07 & $-0.01 \pm$ & 0.11 & $2500 \pm$ & 50 & 31 \\
\hline TMOll-120 & $11 / 21 / 91$ & 9.63 & 347 & $0.040 \pm$ & 0.02 & $3.0 \pm$ & 0.2 & $-0.09 \pm$ & 0.07 & $0.14 \pm$ & 0.10 & $1700 \pm$ & 15 & 9.9 \\
\hline TMOII-122 & $12 / 02 / 91$ & 8.88 & 114 & $0.030 \pm$ & 0.022 & $0.38 \pm$ & 0.08 & $0.09 \pm$ & 0.11 & $0.05 \pm$ & 0.17 & $290 \pm$ & 50 & 1.0 \\
\hline TMOII-124 & $12 / 11 / 91$ & 8.73 & 312 & $0.010 \pm$ & 0.018 & $0.71 \pm$ & 0.10 & $-0.01 \pm$ & 0.06 & $-0.02 \pm$ & 0.09 & $1200 \pm$ & 18 & 1.7 \\
\hline TMOII-126 & $12 / 23 / 91$ & 8.63 & 104 & $0.01 \pm$ & 0.05 & $1.8 \pm$ & 0.3 & $0.04 \pm$ & 0.06 & $0.01 \pm$ & 0.11 & $-60 \pm$ & 25 & 1.9 \\
\hline TMOll-128 & $12 / 30 / 91$ & 8.31 & 183 & $0.013 \pm$ & 0.03 & $1.5 \pm$ & 0.2 & $-0.07 \pm$ & 0.04 & $-0.01 \pm$ & 0.07 & $810 \pm$ & 25 & 2.2 \\
\hline TMOII-130 & $01 / 03 / 92$ & 9.41 & 130 & $0.062 \pm$ & 0.045 & $1.0 \pm$ & 0.2 & $0.04 \pm$ & 0.04 & $-0.01 \pm$ & 0.10 & $270 \pm$ & 50 & 2.6 \\
\hline
\end{tabular}

- Radionuclide data are in Becquerel/liter, mean \pm standard counting error; specific conductance in microsiemens/centimeter; TOC in mg/L.

- Gross beta analysis does not include tritium

c TOC = total organic carbon 
Table B.2. Field parameters and radionuclide concentrations in tumulus underpad drainage*

\begin{tabular}{|c|c|c|c|c|c|c|c|c|c|}
\hline Sample & Date & $\mathrm{pH}$ & $\begin{array}{c}\text { Specific } \\
\text { conductance }\end{array}$ & Gross Alpha & Gross Beta & ${ }^{60} \mathrm{Co}$ & ${ }^{137} \mathrm{Cs}$ & ${ }^{3} \mathrm{H}$ & \\
\hline \multicolumn{10}{|c|}{ Tumulus I construction base drain: } \\
\hline $\begin{array}{c}\text { TMOI-460PWT } \\
\text { TUM-PWT }\end{array}$ & $\begin{array}{l}12 / 02 / 91 \\
06 / 04 / 92\end{array}$ & $\begin{array}{l}7.96 \\
7.59\end{array}$ & 207 & $0.002 \pm 0.048$ & $0.22 \pm 0.18$ & $0.09 \pm 0.16$ & $-0.01 \pm 0.15$ & $560 \pm$ & 20 \\
\hline \multicolumn{10}{|c|}{ Tumulus I underpad: } \\
\hline $\begin{array}{l}\text { TMOI-452UND } \\
\text { TMOI-460UND } \\
\text { TUMI-UND } \\
\text { TUMI--UND }\end{array}$ & $\begin{array}{l}10 / 16 / 91 \\
12 / 02 / 91 \\
07 / 06 / 92 \\
09 / 18 / 92\end{array}$ & $\begin{array}{l}8.46 \\
8.81 \\
7.53 \\
7.37\end{array}$ & $\begin{array}{l}877 \\
259 \\
815\end{array}$ & $\begin{array}{r}0.14 \pm 0.05 \\
-0.024 \pm 0.009 \\
0.050 \pm 0.096\end{array}$ & $\begin{array}{rr}1.0 & \pm 0.1 \\
0.54 & \pm 0.24 \\
1.8 & \pm 0.4\end{array}$ & $\begin{array}{r}0.13 \pm 0.23 \\
-0.01 \pm 0.13 \\
0.14 \pm 0.10\end{array}$ & $\begin{array}{r}-0.40 \pm 0.28 \\
0.05 \pm 0.11 \\
0.03 \pm 0.12\end{array}$ & $\begin{array}{l}300 \pm \\
160 \pm\end{array}$ & $\begin{array}{l}20 \\
15\end{array}$ \\
\hline \multicolumn{10}{|c|}{ Tumulus II underpad: } \\
\hline $\begin{array}{l}\text { TMOII-114UND } \\
\text { TMOII-122UND } \\
\text { TUMII-UND } \\
\text { TUMII-UND } \\
\text { TUMII-UND }\end{array}$ & $\begin{array}{l}10 / 16 / 91 \\
12 / 02 / 91 \\
05 / 29 / 92 \\
07 / 06 / 92 \\
09 / 18 / 92\end{array}$ & $\begin{array}{l}8.24 \\
7.51 \\
8.00 \\
7.45 \\
7.75\end{array}$ & $\begin{array}{l}599 \\
527 \\
450 \\
\\
568\end{array}$ & $\begin{array}{r}0.054 \pm 0.032 \\
0.048 \pm 0.093 \\
-0.028 \pm 0.053\end{array}$ & $\begin{array}{l}0.65 \pm 0.10 \\
0.15 \pm 0.18 \\
0.34 \pm 0.20\end{array}$ & $\begin{array}{l}0.02 \pm 0.17 \\
0.01 \pm 0.20 \\
0.02 \pm 0.14\end{array}$ & $\begin{array}{r}-0.08 \pm 0.15 \\
0.05 \pm 0.20 \\
-0.01 \pm 0.12\end{array}$ & $\begin{array}{r}3100 \pm \\
19000 \pm\end{array}$ & $\begin{array}{r}50 \\
500\end{array}$ \\
\hline
\end{tabular}

- Radionuclide data are in Becquerel/L, mean \pm standard counting error; specific conductivity in microsiemens/centimeter; blanks indicate analysis not performed.

b Gross beta analysis does not include tritium 
Table B.3. Field parameters and radionuclide concentrations in the IWMF pad water runoff

\begin{tabular}{|c|c|c|c|c|c|c|c|c|c|c|}
\hline Sample & Date & pH & $\begin{array}{c}\text { Specific } \\
\text { conductance }\end{array}$ & Gross Âlpha & Gross Beta & ${ }^{n} \mathrm{Co}$ & & ${ }^{137} \mathrm{Cs}$ & ${ }^{3} \mathrm{H}$ & TOC \\
\hline \multicolumn{11}{|c|}{ IWMFd pad No. 1 (active pad): } \\
\hline IWMF-000 & $12 / 23 / 91$ & 8.24 & 129 & $0.030 \pm 0.039$ & $0.92 \pm 0.16$ & $-0.19 \pm$ & 0.14 & $0.03 \pm 0.10$ & $-81 \pm 17$ & 2.7 \\
\hline IWMF-002 & $12 / 30 / 91$ & 7.89 & 103 & $0.052 \pm 0.043$ & $0.58 \pm 0.13$ & $-0.04 \pm$ & 0.10 & $0.05 \pm 0.09$ & $23 \pm 14$ & 1.2 \\
\hline IWMF-006 & $01 / 03 / 92$ & 8.36 & 84 & $0.067 \pm 0.048$ & $0.33 \pm 0.12$ & $0.16 \pm$ & 0.09 & $-0.05 \pm 0.14$ & $-120 \pm 15$ & 1.1 \\
\hline IWMF-008 & $01 / 13 / 92$ & 8.96 & 172 & $0.062 \pm 0.032$ & $0.45 \pm 0.08$ & $0.08 \pm$ & 0.08 & $0.01 \pm 0.08$ & & 10 \\
\hline IWMF-010 & $01 / 23 / 92$ & 7.10 & 98 & $0.073 \pm 0.033$ & $0.70 \pm 0.10$ & $-0.05 \pm$ & 0.13 & $0.01 \pm 0.11$ & $49 \pm 12$ & 2.8 \\
\hline IWMF-011 & $01 / 23 / 92$ & & & $0.40 \pm 0.07$ & $0.33 \pm 0.07$ & $0.03 \pm$ & 0.08 & $-0.04 \pm 0.09$ & & \\
\hline IWMF-012 & $02 / 13 / 92$ & 6.83 & 226 & $0.040 \pm 0.028$ & $1.3 \pm 0.2$ & $-0.3 \pm$ & 1.2 & $-0.9 \pm 1.3$ & $50 \pm 13$ & 8 \\
\hline IWMF-013 & $02 / 13 / 92$ & & & $0.058 \pm 0.033$ & $0.21 \pm 0.07$ & $0.6 \pm$ & 1.0 & $-0.4 \pm 1.2$ & & \\
\hline IWMF-014 & $02 / 18 / 92$ & 9.18 & 241 & $0.040 \pm 0.031$ & $1.2 \pm 0.1$ & $-0.1 \pm$ & 1.1 & $1.1 \pm 1.0$ & $63 \pm 13$ & 5.3 \\
\hline IWMF-015 & $02 / 18 / 92$ & & & $-0.004 \pm 0.015$ & $0.04 \pm 0.06$ & $0.6 \pm$ & 0.6 & $1.5 \pm 0.9$ & & \\
\hline IWMF-016 & $03 / 06 / 92$ & 7.18 & 229 & $0.054 \pm 0.030$ & $2.0 \pm 0.2$ & $-0.2 \pm$ & 0.9 & $-0.4 \pm 0.9$ & $51 \pm 13$ & 30 \\
\hline IWMF-017 & $03 / 06 / 92$ & & & $-0.014 \pm 0.020$ & $-0.07 \pm 0.07$ & $0.05 \pm$ & 0.37 & $0.04 \pm 0.38$ & & \\
\hline IWMF-018 & $03 / 18 / 92$ & 7.83 & 261 & $0.014 \pm 0.024$ & $1.4 \pm 0.2$ & $1.1 \pm$ & 0.2 & $1.1 \pm 0.4$ & $25 \pm 12$ & 12 \\
\hline IWMF-019 & $03 / 18 / 92$ & & & $0.014 \pm 0.020$ & $0.01 \pm 0.07$ & $0.3 \pm$ & 0.8 & $0.5 \pm 0.6$ & & \\
\hline IWMF-020 & $03 / 26 / 92$ & 6.95 & 273 & $-0.007 \pm 0.020$ & $0.82 \pm 0.10$ & $0.10 \pm$ & 0.06 & $-0.05 \pm 0.11$ & $13 \pm 20$ & 5.8 \\
\hline IWMF-021 & $03 / 26 / 92$ & & & $0.023 \pm 0.021$ & $0.14 \pm 0.06$ & $0.27 \pm$ & 0.08 & $0.08 \pm 0.11$ & & \\
\hline IWMF-022 & $05 / 07 / 92$ & 6.67 & 314 & $0.016 \pm 0.023$ & $2.9 \pm 0.2$ & $0.08 \pm$ & 0.11 & $-0.05 \pm 0.13$ & $82 \pm 14$ & \\
\hline IWMF-023 & $05 / 07 / 92$ & & & $0.026 \pm 0.027$ & $-0.07 \pm 0.05$ & $0.12 \pm$ & 0.15 & $0.12 \pm 0.15$ & & \\
\hline $\begin{array}{l}\text { IWMF-024 } \\
\text { IWMF-025 }\end{array}$ & $\begin{array}{l}05 / 29 / 92 \\
05 / 29 / 92\end{array}$ & 8.33 & 258 & $\begin{array}{r}0.052 \pm 0.036 \\
0.54 \pm 0.10\end{array}$ & $\begin{array}{rr}3.2 & \pm 0.2 \\
0.67 & \pm 0.10\end{array}$ & $\begin{array}{r}-0.04 \pm \\
0.15 \pm\end{array}$ & $\begin{array}{l}0.08 \\
0.04\end{array}$ & $\begin{aligned}-0.04 & \pm 0.08 \\
0.15 & \pm 0.04\end{aligned}$ & $370 \pm 20$ & 33 \\
\hline IWMF-026 & $06 / 09 / 92$ & 8.14 & 363 & $0.30 \pm 0.08$ & $1.8 \pm 0.2$ & $-0.07 \pm$ & 0.10 & $-0.07 \pm 0.10$ & e & 4.40 \\
\hline IWMF-027 & $06 / 09 / 92$ & & & $0.053 \pm 0.032$ & $0.38 \pm 0.08$ & $0.09 \pm$ & 0.10 & $0.09 \pm 0.10$ & & \\
\hline
\end{tabular}


Table B.3 (continued)

\begin{tabular}{|c|c|c|c|c|c|c|c|c|c|c|}
\hline Sample & Date & $\mathbf{p H}$ & $\begin{array}{c}\text { Specific } \\
\text { conductance }\end{array}$ & Gross Alpha & Gross Beta & ${ }^{60} \mathrm{Co}$ & & ${ }^{137} \mathrm{Cs}$ & ${ }^{3} \mathrm{H}$ & $\mathrm{TOC}^{\mathrm{C}}$ \\
\hline IWMF-028 & $06 / 19 / 92$ & 8.10 & 393 & $-0.005 \pm 0.030$ & $2.1 \pm 0.2$ & $0.23 \pm$ & 0.11 & $0.23 \pm 0.11$ & $55 \pm 15$ & 4.68 \\
\hline IWMF-029 & $06 / 19 / 92$ & & & $0.024 \pm 0.031$ & $-0.05 \pm 0.06$ & $0.07 \pm$ & 0.08 & $0.07 \pm 0.08$ & & \\
\hline IWMF-030 & $06 / 30 / 92$ & 9.41 & 539 & $0.07 \pm 0.11$ & $6.9 \pm 0.6$ & $0.11 \pm$ & 0.13 & $0.11 \pm 0.13$ & $170 \pm 20$ & 26 \\
\hline IWMF-031 & $06 / 30 / 92$ & & & $0.10 \pm 0.10$ & $0.13 \pm 0.33$ & $0.12 \pm$ & 0.06 & $0.12 \pm 0.06$ & & \\
\hline IWMF-032 & $08 / 03 / 92$ & 8.97 & 285 & $0.054 \pm 0.045$ & $2.0 \pm 0.2$ & $0.01 \pm$ & 0.08 & $0.15 \pm 0.09$ & & 3.6 \\
\hline IWMF-034 & $08 / 13 / 92$ & 8.78 & 337 & $0.034 \pm 0.030$ & $2.0 \pm 0.2$ & $0.01 \pm$ & 0.09 & $0.01 \pm 0.09$ & $42 \pm 13$ & 4.0 \\
\hline IWMF-035 & $08 / 13 / 92$ & & & $-0.019 \pm 0.020$ & $0.10 \pm 0.07$ & $0.05 \pm$ & 0.07 & $0.05 \pm 0.07$ & & \\
\hline IWMF-036 & $08 / 17 / 92$ & 9.61 & 421 & $0.031 \pm 0.028$ & $2.9 \pm 0.2$ & $-0.03 \pm$ & 0.11 & $-0.03 \pm 0.11$ & $62 \pm 14$ & 4.2 \\
\hline IWMF-037 & $08 / 17 / 92$ & & & $0.014 \pm 0.020$ & $0.04 \pm 0.05$ & $-0.03 \pm$ & 0.07 & $-0.03 \pm 0.07$ & & \\
\hline IWMF-038 & $08 / 24 / 92$ & 8.84 & 354 & $0.012 \pm 0.035$ & $2.1 \pm 0.2$ & $0.14 \pm$ & 0.06 & $0.14 \pm 0.06$ & $130 \pm 15$ & 3.9 \\
\hline IWMF-039 & $08 / 24 / 92$ & & & $0.12 \pm 0.06$ & $0.30 \pm 0.11$ & $0.23 \pm$ & 0.07 & $0.23 \pm 0.07$ & & \\
\hline IWMF-040 & $09 / 18 / 92$ & 9.65 & 302 & $0.08 \pm 0.05$ & $2.4 \pm 0.2$ & $0.03 \pm$ & 0.08 & $0.05 \pm 0.08$ & $56 \pm 13$ & 7.2 \\
\hline IWMF-041 & $09 / 18 / 92$ & & & $0.019 \pm 0.034$ & $-0.02 \pm 0.07$ & $0.07 \pm$ & 0.12 & $0.08 \pm 0.10$ & & \\
\hline IWMF-042 & $09 / 22 / 92$ & 8.98 & 274 & $-0.004 \pm 0.023$ & $4.5 \pm 0.2$ & $0.16 \pm$ & 0.08 & $0.06 \pm 0.12$ & $62 \pm 13$ & 4.1 \\
\hline \multicolumn{11}{|c|}{ IWMF pad $* 2$ (inactive pad): } \\
\hline IWMF2-000 & $09 / 18 / 92$ & 8.40 & 81 & & & & & & $25 \pm 25$ & 2.4 \\
\hline
\end{tabular}

- Radionuclide data are in Becquerelliter, mean \pm standard counting error; specific conductance in microsiemens/centimeter.

- Gross beta analysis does not include tritium

- $T O C=$ total organic carbon; data in milligrams/liter.

$\checkmark$ IWMF = Interim Waste Management Facility: odd sample numbers are blanks

- Sample bottle broken during analysis. 
Table B.4. Field parameters and radionuclide concentrations in tumulus area monitoring wells"

\begin{tabular}{|c|c|c|c|c|c|c|c|c|c|c|c|}
\hline Well & Date & pH & $\begin{array}{c}\text { Specific } \\
\text { conductance }\end{array}$ & Gross alpha & Gross beta ${ }^{b}$ & \multicolumn{2}{|l|}{${ }^{60} \mathrm{Co}$} & \multicolumn{2}{|l|}{${ }^{137} \mathrm{Cs}$} & \multicolumn{2}{|c|}{ Tritium } \\
\hline 1036 & $09 / 26 / 91$ & 6.4 & 353 & $0.15 \pm 0.05$ & $0.40 \pm 0.08$ & $0.8 \pm$ & 0.8 & $-0.3 \pm$ & 1.2 & $11000 \pm$ & 500 \\
\hline 1037 & $09 / 26 / 91$ & 5.1 & 199 & $0.054 \pm 0.032$ & $0.29 \pm 0.09$ & $0.8 \pm$ & 1.0 & $-1.4 \pm$ & 1.4 & $470 \pm$ & 20 \\
\hline 1038 & $09 / 26 / 91$ & 6.1 & 687 & $0.078 \pm 0.042$ & $0.28 \pm 0.09$ & $0.6 \pm$ & 1.0 & $0.3 \pm$ & 1.2 & $170 \pm$ & 15 \\
\hline 1039 & $09 / 26 / 91$ & 6.2 & 625 & $0.13 \pm 0.04$ & $0.21 \pm 0.07$ & $0.5 \pm$ & 1.1 & $0.8 \pm$ & 1.0 & $510 \pm$ & 20 \\
\hline 1040 & $09 / 26 / 91$ & 6.5 & 377 & $0.094 \pm 0.040$ & $0.20 \pm 0.08$ & $-0.8 \pm$ & 1.4 & $-0.9 \pm$ & 1.3 & $70 \pm$ & 15 \\
\hline 1254 & $09 / 26 / 91$ & 6.9 & 367 & $0.17 \pm 0.05$ & $0.16 \pm 0.07$ & $1.5 \pm$ & 1.0 & $-0.1 \pm$ & 1.3 & $40 \pm$ & 13 \\
\hline 1255 & $09 / 26 / 91$ & 6.8 & 413 & $0.089 \pm 0.041$ & $0.29 \pm 0.08$ & $0.3 \pm$ & 1.3 & $-0.9 \pm$ & 1.4 & $110 \pm$ & 15 \\
\hline 1256 & $09 / 26 / 91$ & 6.2 & 659 & $0.19 \pm 0.05$ & $0.21 \pm 0.07$ & $-0.28 \pm$ & 0.17 & $-0.01 \pm$ & 0.12 & $150 \pm$ & 15 \\
\hline 1257 & $09 / 26 / 91$ & 6.7 & 414 & $0.096 \pm 0.043$ & $0.11 \pm 0.08$ & $0.06 \pm$ & 0.09 & $0.06 \pm$ & 0.10 & $160 \pm$ & 15 \\
\hline 1258 & $09 / 26 / 91$ & 6.0 & 289 & $0.031 \pm 0.028$ & $0.09 \pm 0.08$ & $-0.9 \pm$ & 1.4 & $-2.0 \pm$ & 1.4 & $130 \pm$ & 15 \\
\hline 1259 & $09 / 26 / 91$ & 5.5 & 213 & $0.15 \pm 0.05$ & $0.03 \pm 0.06$ & $-3.0 \pm$ & 1.7 & $0.4 \pm$ & 1.2 & $18 \pm$ & 25 \\
\hline 1036 & $01 / 15 / 92$ & 6.1 & 304 & $0.027 \pm 0.025$ & $0.09 \pm 0.08$ & $0.13 \pm$ & 0.13 & $0.04 \pm$ & 0.15 & $14000 \pm$ & 500 \\
\hline 1037 & $01 / 15 / 92$ & 5.5 & 121 & $0.038 \pm 0.027$ & $0.16 \pm 0.07$ & $-0.08 \pm$ & 0.15 & $0.07 \pm$ & 0.11 & $5600 \pm$ & 50 \\
\hline 1038 & $01 / 15 / 92$ & 6.4 & 617 & $0.030 \pm 0.026$ & $0.07 \pm 0.06$ & $0.17 \pm$ & 0.10 & $0.08 \pm$ & 0.11 & $260 \pm$ & 20 \\
\hline 1039 & $01 / 15 / 92$ & 6.2 & 552 & $0.031 \pm 0.027$ & $0.12 \pm 0.07$ & $0.02 \pm$ & 0.09 & $-0.02 \pm$ & 0.08 & $320 \pm$ & 20 \\
\hline 1040 & $01 / 15 / 92$ & 6.4 & 341 & $-0.017 \pm 0.013$ & $-0.07 \pm 0.08$ & $0.05 \pm$ & 0.17 & $0.04 \pm$ & 0.16 & $0 \pm$ & 16 \\
\hline 1254 & $01 / 15 / 92$ & 6.6 & 279 & $0.026 \pm 0.024$ & $0.09 \pm 0.06$ & $0.04 \pm$ & 0.12 & $0.02 \pm$ & 0.13 & $-83 \pm$ & 15 \\
\hline 1255 & $01 / 15 / 92$ & 6.3 & 483 & $-0.005 \pm 0.018$ & $0.10 \pm 0.07$ & $-0.13 \pm$ & 0.22 & $-0.09 \pm$ & 0.16 & $51 \pm$ & 17 \\
\hline 1256 & $01 / 15 / 92$ & 6.5 & 621 & $-0.017 \pm 0.014$ & $0.04 \pm 0.06$ & $0.16 \pm$ & 0.11 & $-0.03 \pm$ & 0.14 & $140 \pm$ & 20 \\
\hline 1257 & $01 / 15 / 92$ & 6.5 & 166 & $0.007 \pm 0.022$ & $0.08 \pm 0.07$ & $0.05 \pm$ & 0.09 & $-0.02 \pm$ & 0.07 & $130 \pm$ & 20 \\
\hline 1258 & $01 / 15 / 92$ & 6.8 & 167 & $0.079 \pm 0.036$ & $0.16 \pm 0.08$ & $0.01 \pm$ & 0.17 & $0.03 \pm$ & 0.14 & $320 \pm$ & 20 \\
\hline 1259 & $C: / 15 / 92$ & 5.9 & 46 & $0.062 \pm 0.032$ & $0.12 \pm 0.06$ & $-0.08 \pm$ & 0.13 & $-0.01 \pm$ & 0.13 & $71 \pm$ & 17 \\
\hline 1036 & $04 / 06 / 92$ & 6.4 & 349 & $-0.030 \pm 0.005$ & $0.25 \pm 0.07$ & $0.01 \pm$ & 0.11 & $0.09 \pm$ & 0.10 & $14000 \pm$ & 500 \\
\hline 1037 & $04 / 06 / 92$ & 5.4 & 134 & $-0.005 \pm 0.018$ & $-0.07 \pm 0.05$ & $0.2 \pm$ & 0.1 & $0.04 \pm$ & 0.09 & $2700 \pm$ & 50 \\
\hline
\end{tabular}


Table B.4 (continued)

\begin{tabular}{|c|c|c|c|c|c|c|c|c|c|}
\hline Well & Date & $\mathrm{pH}$ & $\begin{array}{c}\text { Specific } \\
\text { conductance }\end{array}$ & Gross alpha & Gross beta ${ }^{b}$ & ${ }^{60} \mathrm{Co}$ & ${ }^{137} \mathrm{Cs}$ & Tritium & \\
\hline 1038 & 04/06/92 & 6.2 & 441 & $0.002 \pm 0.018$ & $0.22 \pm 0.08$ & $-0.07 \pm 0.12$ & $0.07 \pm 0.11$ & $580 \pm$ & 20 \\
\hline 1039 & $04 / 06 / 92$ & 6.4 & 577 & $0.039 \pm 0.028$ & $0.07 \pm 0.07$ & $0.02 \pm 0.12$ & $-0.06 \pm 0.12$ & $460 \pm$ & 20 \\
\hline 1040 & $04 / 06 / 92$ & 6.5 & 326 & $-0.022 \pm 0.005$ & $0.04 \pm 0.07$ & $0.02 \pm 0.15$ & $0.12 \pm 0.13$ & $66 \pm$ & 14 \\
\hline 1254 & $04 / 06 / 92$ & 7.0 & 370 & $0.038 \pm 0.027$ & $0.21 \pm 0.07$ & $-0.05 \pm 0.14$ & $-0.02 \pm 0.12$ & $-19 \pm$ & 12 \\
\hline 1255 & $04 / 06 / 92$ & 6.8 & 401 & $0.008 \pm 0.022$ & $0.07 \pm 0.07$ & $0.01 \pm 0.18$ & $0.1 \pm 0.1$ & $100 \pm$ & 15 \\
\hline 1256 & 04/06/92 & 6.4 & 669 & $0.082 \pm 0.035$ & $0.13 \pm 0.07$ & $0.02 \pm 0.18$ & $0.16 \pm 0.15$ & $180 \pm$ & 15 \\
\hline 1257 & $04 / 06 / 92$ & 6.6 & 499 & $0.007 \pm 0.022$ & $0.08 \pm 0.07$ & $0.05 \pm 0.09$ & $-0.02 \pm 0.07$ & $160 \pm$ & 15 \\
\hline 1258 & $04 / 06 / 92$ & 6.0 & 296 & $0.073 \pm 0.037$ & $0.12 \pm 0.07$ & $0.06 \pm 0.31$ & $-0.27 \pm 0.32$ & $510 \pm$ & 20 \\
\hline 1259 & $04 / 06 / 92$ & 5.6 & 167 & $-0.013 \pm 0.019$ & $0.14 \pm 0.08$ & $-0.09 \pm 0.15$ & $-0.09 \pm 0.13$ & $250 \pm$ & 15 \\
\hline 1036 & 07/21/92 & 6.6 & 326 & $0.072 \pm 0.037$ & $0.15 \pm 0.07$ & $-0.10 \pm 0.14$ & $-0.05 \pm 0.12$ & $14000 \pm$ & 500 \\
\hline 1037 & 07/21/92 & 5.9 & 128 & $0.034 \pm 0.025$ & $-0.02 \pm 0.06$ & $0.02 \pm 0.08$ & $0.07 \pm 0.06$ & $2300 \pm$ & 50 \\
\hline 1038 & $07 / 17 / 92$ & 4.9 & 521 & $-0.024 \pm 0.005$ & $0.64 \pm 0.13$ & $0.22 \pm 0.10$ & $0.17 \pm 0.13$ & $1300 \pm$ & 50 \\
\hline 1039 & $07 / 17 / 92$ & 6.3 & 483 & $0.07 \pm 0.05$ & $0.05 \pm 0.08$ & $-0.05 \pm 0.08$ & $-0.01 \pm 0.07$ & $1200 \pm$ & 50 \\
\hline 1040 & $07 / 16 / 92$ & 6.8 & 347 & $0.063 \pm 0.033$ & $0.25 \pm 0.07$ & $-0.06 \pm 0.18$ & $0.12 \pm 0.18$ & $84 \pm$ & 21 \\
\hline 1254 & 07/16/92 & 7.2 & 348 & $0.13 \pm 0.05$ & $0.29 \pm 0.07$ & $0.17 \pm 0.08$ & $-0.06 \pm 0.18$ & $9 \pm$ & 14 \\
\hline 1255 & $07 / 16 / 92$ & 7.2 & 371 & $0.058 \pm 0.030$ & $0.23 \pm 0.07$ & $0.10 \pm 0.14$ & $0.10 \pm 0.11$ & $110 \pm$ & 15 \\
\hline 1256 & $07 / 21 / 92$ & 6.5 & 690 & $0.092 \pm 0.039$ & $0.10 \pm 0.06$ & $0.21 \pm 0.17$ & $0.01 \pm 0.16$ & $230 \pm$ & 15 \\
\hline 1257 & $07 / 21 / 92$ & 7.0 & 396 & $0.083 \pm 0.038$ & $0.14 \pm 0.06$ & $-0.22 \pm 0.29$ & $0.03 \pm 0.24$ & $170 \pm$ & 15 \\
\hline 1258 & 07/21/92 & 6.5 & 262 & $0.062 \pm 0.032$ & $0.02 \pm 0.06$ & $0.04 \pm 0.15$ & $0.18 \pm 0.15$ & $690 \pm$ & 25 \\
\hline 1259 & $07 / 21 / 92$ & 5.5 & 164 & $0.096 \pm 0.038$ & $0.14 \pm 0.06$ & $-0.01 \pm 0.06$ & $0.02 \pm 0.05$ & $340 \pm$ & 20 \\
\hline
\end{tabular}

- Radionuclide data are in Becquerel/liter, mean \pm standard counting error; specific conductance in microsiemens/centimeter.

- Gross beta analysis does not include tritium. 
Table B.5. Tumulus monitoring wells cation and anion data"

\begin{tabular}{|c|c|c|c|c|c|c|c|c|c|c|c|c|c|c|c|}
\hline Well & Date & $\mathrm{Ba}$ & $\mathrm{Ca}$ & $\mathrm{Fe}$ & $\mathbf{M g}$ & $M n$ & $\mathrm{Na}$ & $\mathrm{Ni}$ & Si & Sr & $\mathrm{Zn}$ & $\mathrm{Cl}$ & $\mathrm{NO}_{3}$ & $\mathrm{SO}_{4}$ & $F$ \\
\hline 1036 & $04 / 06 / 92$ & 0.23 & 56 & $<0.05$ & 7.7 & 0.0028 & 5.0 & 0.005 & 7.6 & 0.092 & $<0.005$ & 4.3 & 1.6 & 8.5 & 0.3 \\
\hline 1037 & $04 / 09 / 92$ & 0.038 & 7.4 & $<0.05$ & 10 & 0.014 & $<5.0$ & 0.11 & 13 & 0.024 & $<0.005$ & 1.8 & 1.4 & 9.9 & $<0.2$ \\
\hline 1038 & $04 / 09 / 92$ & 0.1 & 84 & 0.071 & 18 & 0.051 & 5.1 & 0.061 & 8.3 & 0.16 & $<0.005$ & 2.4 & $<0.5$ & 35.8 & $<0.2$ \\
\hline 1039 & $04 / 06 / 92$ & 0.055 & 100 & $<0.05$ & 14 & 0.012 & 7.0 & 0.017 & 6.7 & 0.15 & $<0.005$ & 3.2 & $<0.5$ & 41.6 & $<0.2$ \\
\hline 1040 & $04 / 06 / 92$ & 0.08 & 57 & $<0.05$ & 14 & 0.0014 & $<5.0$ & 0.029 & 6.8 & 0.096 & $<0.005$ & 3.4 & $<0.5$ & 9.5 & $<0.2$ \\
\hline 1254 & $04 / 07 / 92$ & 0.12 & 61 & $<0.05$ & 7.9 & 0.0073 & 5.8 & $<0.004$ & 10 & 0.26 & 0.034 & 2.4 & $<0.5$ & 17.1 & $<0.2$ \\
\hline 1255 & $04 / 07 / 92$ & 0.15 & 68 & $<0.05$ & 8.2 & 0.011 & $<5.0$ & $<0.004$ & 8.3 & 0.24 & 0.018 & 5.2 & $<0.5$ & 14.9 & $<0.2$ \\
\hline 1256 & $04 / 28 / 92$ & 0.28 & 120 & $<0.05$ & 15 & 0.013 & $<5.0$ & $<0.004$ & 7.2 & 0.22 & 0.011 & 0.8 & $<0.5$ & 0.8 & $<0.2$ \\
\hline 1257 & $04 / 28 / 92$ & 0.24 & 71 & $<0.05$ & 9.6 & 0.024 & $<5.0$ & $<0.004$ & 8.4 & 0.12 & $<0.005$ & 3.8 & 0.7 & 10.4 & $<0.2$ \\
\hline 1258 & 04/09/92 & 0.21 & 52 & $<0.05$ & 3.9 & 0.0017 & $<5.0$ & $<0.004$ & 7.9 & 0.082 & $<0.005$ & 4.6 & 5.9 & 2.5 & $<0.2$ \\
\hline 1259 & $04 / 07 / 92$ & 0.12 & 20 & $<0.05$ & 3.5 & 0.01 & 8.5 & $<0.004$ & 8.5 & 0.047 & 0.013 & 3.7 & 2.5 & 5.7 & $<0.2$ \\
\hline
\end{tabular}

- All data in milligrams per liter. 
Table B.6. Radionuclide concentrations in tumulus area soil samples

\begin{tabular}{|c|c|c|c|c|c|c|c|c|c|}
\hline \multirow{3}{*}{$\begin{array}{c}\text { Sample } \\
1036 \mathrm{~N} \\
1036 \mathrm{~S}\end{array}$} & \multirow{3}{*}{$\begin{array}{c}\text { Date } \\
01 / 22 / 92 \\
01 / 22 / 92\end{array}$} & \multicolumn{2}{|c|}{ Gross alpha } & \multicolumn{2}{|c|}{ Gross beta } & ${ }^{60} \mathrm{Co}$ & ${ }^{137} \mathrm{Cs}$ & \multicolumn{2}{|c|}{${ }^{40} \mathrm{~K}$} \\
\hline & & $1600 \pm$ & 500 & $1500 \pm$ & 650 & $2.2 \pm 1.9$ & $1.1 \pm 2.2$ & $840 \pm$ & 40 \\
\hline & & $690 \pm$ & 275 & $300 \pm$ & 340 & $1.9 \pm 1.7$ & $7.1 \pm 1.4$ & $390 \pm$ & 30 \\
\hline 1037 & $01 / 22 / 92$ & $250 \pm$ & 240 & $1200 \pm$ & 600 & $0.9 \pm 2.0$ & $11 \pm 1.5$ & $470 \pm$ & 25 \\
\hline 1038 & $01 / 22 / 92$ & $570 \pm$ & 1550 & $550 \pm$ & 195 & $-1.1 \pm 2.5$ & $9.9 \pm 1.8$ & $250 \pm$ & 30 \\
\hline 1039 & 01/22/92 & $2100 \pm$ & 550 & $700 \pm$ & 550 & $-0.2 \pm 2.4$ & $4.8 \pm 1.4$ & $580 \pm$ & 35 \\
\hline 1040 & $01 / 22 / 92$ & $1400 \pm$ & 500 & $1800 \pm$ & 600 & $0.4 \pm 1.8$ & $-1.1 \pm 2.5$ & $590 \pm$ & 35 \\
\hline 1254 & $01 / 22 / 92$ & $720 \pm$ & 345 & $1600 \pm$ & 1200 & $0.2 \pm 2.4$ & $3.5 \pm 1.4$ & $590 \pm$ & 40 \\
\hline 1255 & 01/22/92 & $620 \pm$ & 200 & $1200 \pm$ & 350 & $-0.2 \pm 2.4$ & $5.3 \pm 2.0$ & $610 \pm$ & 40 \\
\hline 1256 & $01 / 22 / 92$ & $360 \pm$ & 155 & $1500 \pm$ & 600 & $-1.5 \pm 2.9$ & $0.9 \pm 3.0$ & $750 \pm$ & 45 \\
\hline 1257 & $01 / 22 / 92$ & $1200 \pm$ & 400 & $1200 \pm$ & 450 & $3.4 \pm 1.6$ & $3.3 \pm 1.8$ & $630 \pm$ & 40 \\
\hline 1258 & $01 / 22 / 92$ & $630 \pm$ & 345 & $2000 \pm$ & 650 & $0.2 \pm 2.6$ & $8.3 \pm 1.7$ & $330 \pm$ & 35 \\
\hline 1259 & $01 / 22 / 92$ & $300 \pm$ & 135 & $1300 \pm$ & 300 & $1.9 \pm 1.7$ & $-1.2 \pm 1.9$ & $490 \pm$ & 30 \\
\hline
\end{tabular}

All data are in Becquerel per kilogram, mean \pm standard error. 
Table B.7. FY 1992 radionuclide data from intratrench wells near low-level waste silos in Solid Waste Storage Area 6"

\begin{tabular}{|c|c|c|c|c|c|c|c|c|}
\hline $\begin{array}{l}\text { Well } \\
\text { No. }\end{array}$ & Date & Gross alpha & Gross beta & ${ }^{60} \mathrm{Co}$ & & ${ }^{137} \mathrm{Cs}$ & & $\begin{array}{l}\text { Particulate } \\
{ }^{137} \mathrm{Cs}^{b}\end{array}$ \\
\hline $\begin{array}{l}4 \\
4 \\
4\end{array}$ & $\begin{array}{l}12 / 20 / 91 \\
03 / 04 / 92 \\
06 / 04 / 92\end{array}$ & $\begin{array}{r}0.19 \pm 0.07 \\
0.033 \pm 0.034 \\
0.049 \pm 0.035\end{array}$ & $\begin{array}{l}0.60 \pm 0.15 \\
0.29 \pm 0.09 \\
0.24 \pm 0.10\end{array}$ & $\begin{array}{l}0.1 \pm \\
0.5 \pm \\
0.9 \pm\end{array}$ & $\begin{array}{l}0.5 \\
0.7 \\
0.8\end{array}$ & $\begin{aligned}-0.04 & \pm \\
-0.4 & \pm \\
0.1 \pm & \end{aligned}$ & $\begin{array}{l}0.4 \\
0.9 \\
0.7\end{array}$ & \\
\hline $\begin{array}{l}5 \\
5 \\
5\end{array}$ & $\begin{array}{l}12 / 20 / 91 \\
03 / 04 / 92 \\
06 / 04 / 92\end{array}$ & $\begin{array}{l}0.05 \pm 0.06 \\
0.13 \pm 0.07 \\
0.12 \pm 0.11\end{array}$ & $\begin{array}{r}1.2 \pm 0.2 \\
0.23 \pm 0.15 \\
5.2 \pm 0.5\end{array}$ & $\begin{array}{r}0.4 \pm \\
-0.2 \pm \\
-0.3 \pm\end{array}$ & $\begin{array}{l}0.9 \\
1.4 \\
3.2\end{array}$ & $\begin{array}{r}0.1 \pm \\
-0.7 \pm \\
3.3 \pm\end{array}$ & $\begin{array}{l}0.9 \\
1.4 \\
2.9\end{array}$ & $1.3 \pm 0.2$ \\
\hline $\begin{array}{l}6 \\
6 \\
6 \\
6\end{array}$ & $\begin{array}{l}12 / 20 / 91 \\
03 / 17 / 92 \\
06 / 04 / 92 \\
08 / 31 / 92\end{array}$ & $\begin{array}{rr}0.056 & \pm 0.040 \\
0.039 & \pm 0.032 \\
0.13 & \pm 0.04 \\
0.15 & \pm 0.07\end{array}$ & $\begin{array}{r}1.2 \pm 0.2 \\
0.44 \pm 0.09 \\
0.90 \pm 0.10 \\
1.5 \pm 0.2\end{array}$ & $\begin{aligned} &-0.1 \pm \\
& 1.2 \pm \\
& 0.6 \pm \\
&-0.3 \pm\end{aligned}$ & $\begin{array}{l}0.6 \\
0.7 \\
0.5 \\
1.2\end{array}$ & $\begin{array}{r}0.5 \pm \\
0.1 \pm \\
-0.1 \pm \\
-0.9 \pm\end{array}$ & $\begin{array}{l}0.6 \\
0.7 \\
0.6 \\
1.5\end{array}$ & $\begin{array}{l}0.11 \pm 0.02 \\
0.08 \pm 0.14\end{array}$ \\
\hline $\begin{array}{l}7 \\
7\end{array}$ & $\begin{array}{l}12 / 20 / 91 \\
03 / 17 / 92\end{array}$ & $\begin{array}{l}0.015 \pm 0.043 \\
0.080 \pm 0.050\end{array}$ & $\begin{array}{r}1.1 \pm 0.2 \\
0.57 \pm 0.18\end{array}$ & $\begin{array}{l}0.5 \pm \\
1.7 \pm\end{array}$ & $\begin{array}{l}0.5 \\
1.1\end{array}$ & $\begin{array}{r}-0.1 \pm \\
0.5 \pm\end{array}$ & $\begin{array}{l}0.6 \\
1.4\end{array}$ & \\
\hline $\begin{array}{l}8 \\
8 \\
8\end{array}$ & $\begin{array}{l}12 / 20 / 91 \\
03 / 17 / 92 \\
06 / 04 / 92\end{array}$ & $\begin{array}{rr}0.010 & \pm 0.026 \\
0.12 & \pm 0.05 \\
0.14 & \pm 0.05\end{array}$ & $\begin{array}{r}0.99 \pm 0.15 \\
0.99 \pm 0.12 \\
1.0 \pm 0.1\end{array}$ & $\begin{array}{r}0.3 \pm \\
-0.1 \pm \\
1.3 \pm\end{array}$ & $\begin{array}{l}0.9 \\
1.1 \\
0.8\end{array}$ & $\begin{array}{r}0.4 \pm \\
0.4 \pm \\
-1.0 \pm\end{array}$ & $\begin{array}{l}0.7 \\
0.9 \\
1.2\end{array}$ & $\begin{array}{l}0.19 \pm 0.07 \\
1.06 \pm 0.42\end{array}$ \\
\hline $\begin{array}{l}10 \\
10 \\
10\end{array}$ & $\begin{array}{l}12 / 20 / 91 \\
06 / 04 / 92 \\
08 / 28 / 92\end{array}$ & $\begin{aligned}-0.011 & \pm 0.023 \\
0.001 & \pm 0.046 \\
0.12 & \pm 0.07\end{aligned}$ & $\begin{array}{r}0.39 \pm 0.11 \\
0.62 \pm 0.17 \\
1.1 \pm 0.2\end{array}$ & $\begin{array}{l}-0.1 \pm \\
-1.7 \pm \\
-1.7 \pm\end{array}$ & $\begin{array}{l}0.8 \\
2.1 \\
1.9\end{array}$ & $\begin{array}{r}-0.1 \pm \\
0.8 \pm \\
0.8 \pm\end{array}$ & $\begin{array}{l}0.6 \\
1.5 \\
1.3\end{array}$ & \\
\hline $\begin{array}{l}11 \\
11 \\
11 \\
11\end{array}$ & $\begin{array}{l}12 / 20 / 91 \\
03 / 04 / 92 \\
06 / 04 / 92 \\
08 / 28 / 92\end{array}$ & $\begin{aligned} 0.035 & \pm 0.041 \\
0.010 & \pm 0.025 \\
0.10 & \pm 0.04 \\
0.057 & \pm 0.033\end{aligned}$ & $\begin{array}{l}0.55 \pm 0.12 \\
0.19 \pm 0.12 \\
0.23 \pm 0.07 \\
0.38 \pm 0.09\end{array}$ & $\begin{array}{l}-0.3 \pm \\
-0.4 \pm \\
-0.8 \pm \\
-0.7 \pm\end{array}$ & $\begin{array}{l}0.7 \\
1.0 \\
1.1 \\
1.4\end{array}$ & $\begin{aligned}-0.04 & \pm \\
-0.8 & \pm \\
-0.4 & \pm \\
0.3 & \pm\end{aligned}$ & $\begin{array}{r}0.46 \\
0.8 \\
0.8 \\
1.3\end{array}$ & \\
\hline
\end{tabular}


Table B.7 (continued)

\begin{tabular}{|c|c|c|c|c|c|c|c|}
\hline $\begin{array}{l}\text { Well } \\
\text { No. }\end{array}$ & Date & Gross alpha & Gross beta & ${ }^{60} \mathrm{Co}$ & \multicolumn{2}{|l|}{${ }^{137} \mathrm{Cs}$} & $\begin{array}{l}\text { Particulate } \\
{ }^{137} \mathrm{Cs}^{b}\end{array}$ \\
\hline 12 & $12 / 20 / 91$ & $0.056 \pm 0.033$ & $0.22 \pm 0.07$ & $-0.4 \pm 1.0$ & $-0.1 \pm$ & 0.8 & \\
\hline 12 & $03 / 04 / 92$ & $0.046 \pm 0.043$ & $0.10 \pm 0.12$ & $0.4 \pm 1.2$ & $-0.4 \pm$ & 1.1 & \\
\hline 13 & $12 / 20 / 91$ & $0.004 \pm 0.029$ & $2.4 \pm 0.2$ & $1.4 \pm 0.5$ & $0.5 \pm$ & 0.8 & $3.1 \pm 0.6$ \\
\hline 13 & $03 / 04 / 92$ & $0.19 \pm 0.10$ & $2.0 \pm 0.3$ & $-3.9 \pm 3.6$ & $-0.1 \pm$ & 2.6 & $1.2 \pm 0.2$ \\
\hline 13 & $08 / 28 / 92$ & $0.56 \pm 0.18$ & $4.3 \pm 0.4$ & $-1.3 \pm 2.8$ & $1.0 \pm$ & 2.1 & $0.56 \pm 0.53$ \\
\hline 15 & $12 / 20 / 91$ & $0.052 \pm 0.043$ & $0.14 \pm 0.11$ & $-0.1 \pm 1.0$ & $0.3 \pm$ & 0.7 & \\
\hline 15 & $03 / 04 / 92$ & $0.06 \pm 0.05$ & $0.21 \pm 0.11$ & $0.2 \pm 0.8$ & $0.3 \pm$ & 0.7 & \\
\hline 15 & $06 / 04 / 92$ & $0.003 \pm 0.019$ & $-0.04 \pm 0.07$ & $-1.7 \pm 1.3$ & $0.1 \pm$ & 1.0 & $0.12 \pm 0.09$ \\
\hline 15 & $08 / 28 / 92$ & $0.063 \pm 0.036$ & $0.47 \pm 0.09$ & $-0.2 \pm 1.4$ & $0.4 \pm$ & 1.1 & $0.11 \pm 0.04$ \\
\hline 16 & $06 / 04 / 92$ & $0.039 \pm 0.050$ & $0.18 \pm 0.13$ & $-1.2 \pm 1.8$ & $0.5 \pm$ & 1.3 & \\
\hline 17 & $12 / 20 / 91$ & $-0.024 \pm 0.005$ & $0.41 \pm 0.12$ & $-0.3 \pm 0.7$ & $0.2 \pm$ & 0.5 & \\
\hline 17 & $03 / 04 / 92$ & $0.065 \pm 0.034$ & $0.68 \pm 0.10$ & $-0.2 \pm 0.6$ & $0.30 \pm$ & 0.44 & \\
\hline 17 & $06 / 04 / 92$ & $-0.005 \pm 0.026$ & $0.80 \pm 0.14$ & $1.4 \pm 1.1$ & $0.3 \pm$ & 1.1 & \\
\hline 18 & $12 / 20 / 91$ & $0.09 \pm 0.06$ & $1.0 \pm 0.2$ & $-0.3 \pm 0.5$ & $0.25 \pm$ & 0.39 & $0.06 \pm 0.04$ \\
\hline 19 & $12 / 20 / 91$ & $0.081 \pm 0.042$ & $29 \pm 0.5$ & $-0.3 \pm 1.0$ & $0.7 \pm$ & 0.8 & $0.5 \pm 0.2$ \\
\hline 19 & $03 / 04 / 92$ & $0.030 \pm 0.029$ & $73 \pm$ & $0.8 \pm 0.8$ & $0.6 \pm$ & 0.7 & \\
\hline 20 & $12 / 20 / 91$ & $-0.006 \pm 0.029$ & $0.81 \pm 0.15$ & $-0.1 \pm 0.8$ & $-0.1 \pm$ & 0.8 & \\
\hline 20 & $03 / 04 / 92$ & $0.075 \pm 0.045$ & $0.20 \pm 0.10$ & $1.2 \pm 0.6$ & $0.6 \pm$ & 0.8 & $0.12 \pm 0.04$ \\
\hline 20 & $08 / 28 / 92$ & $0.30 \pm 0.18$ & $4.5 \pm 0.6$ & $0.3 \pm 3.9$ & $-1.3 \pm$ & 4.3 & \\
\hline 21 & $03 / 04 / 92$ & $0.003 \pm 0.024$ & $1.6 \pm 0.2$ & $-0.4 \pm 0.9$ & $1.1 \pm$ & 0.5 & \\
\hline 21 & $08 / 28 / 92$ & $0.56 \pm 0.26$ & $3.6 \pm 0.7$ & $-1 \pm 5.5$ & $1 \pm$ & 5.0 & \\
\hline
\end{tabular}


Table B.7 (continued)

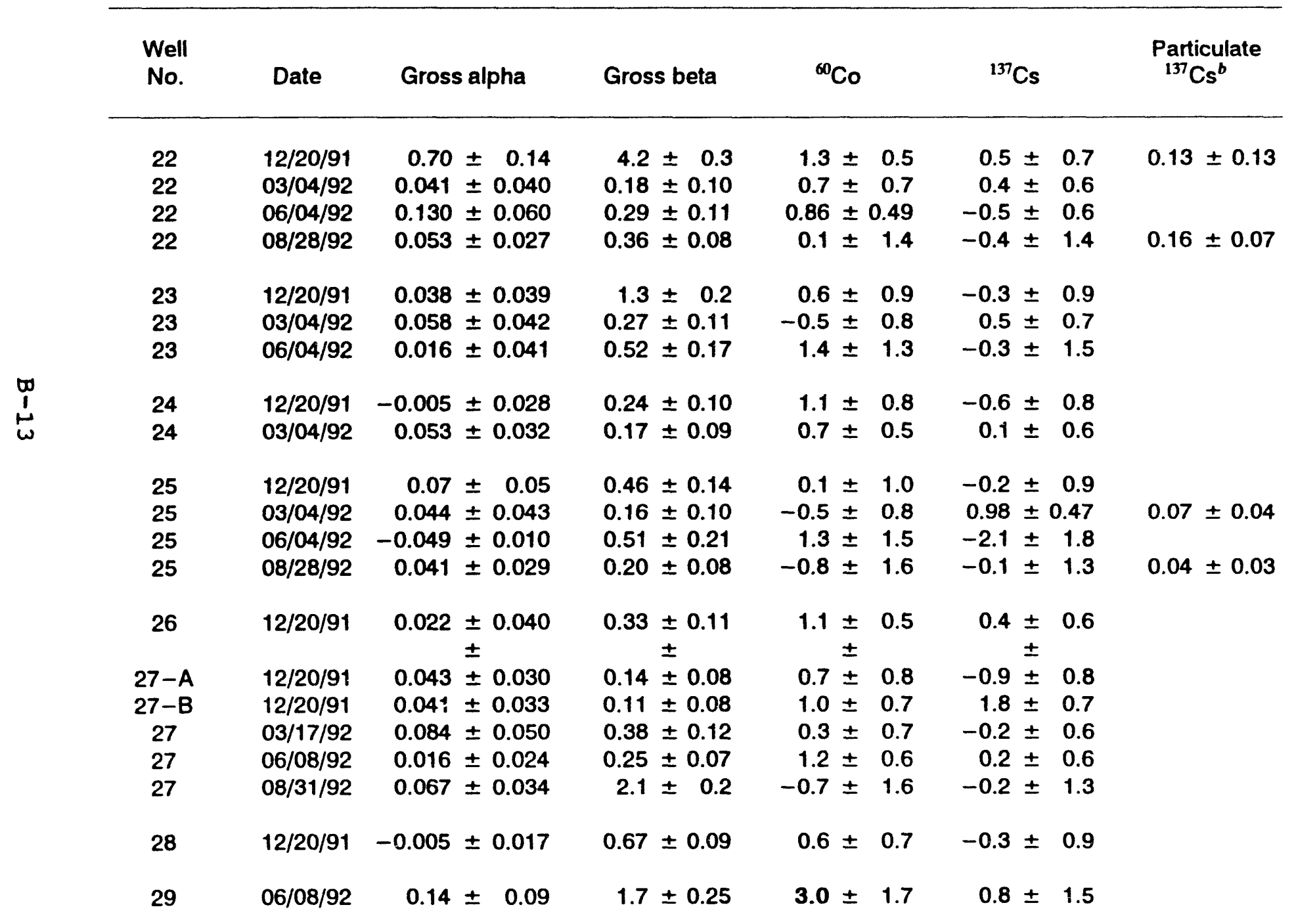


Table B.7 (continued)

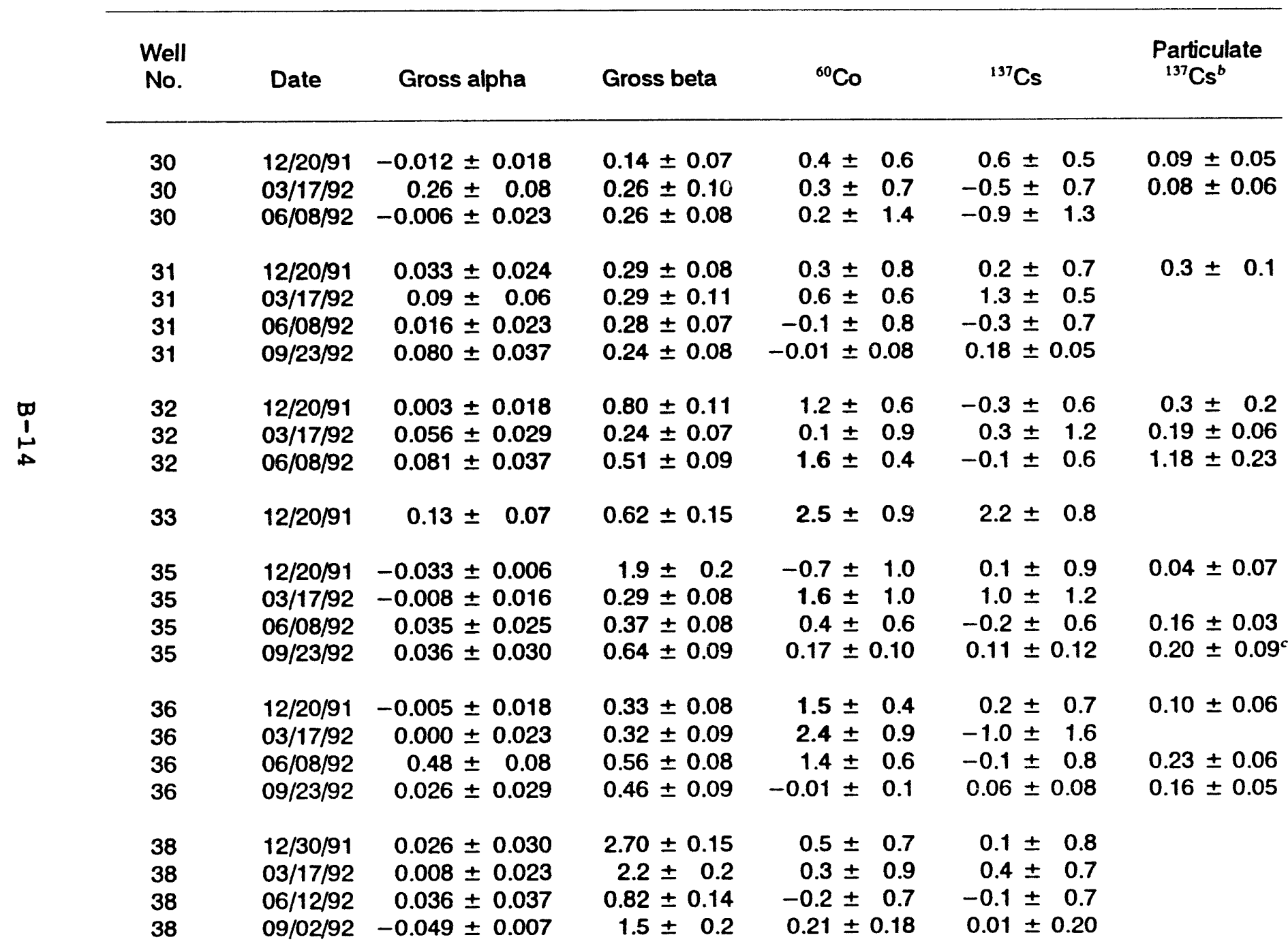


Table B.7 (continued)

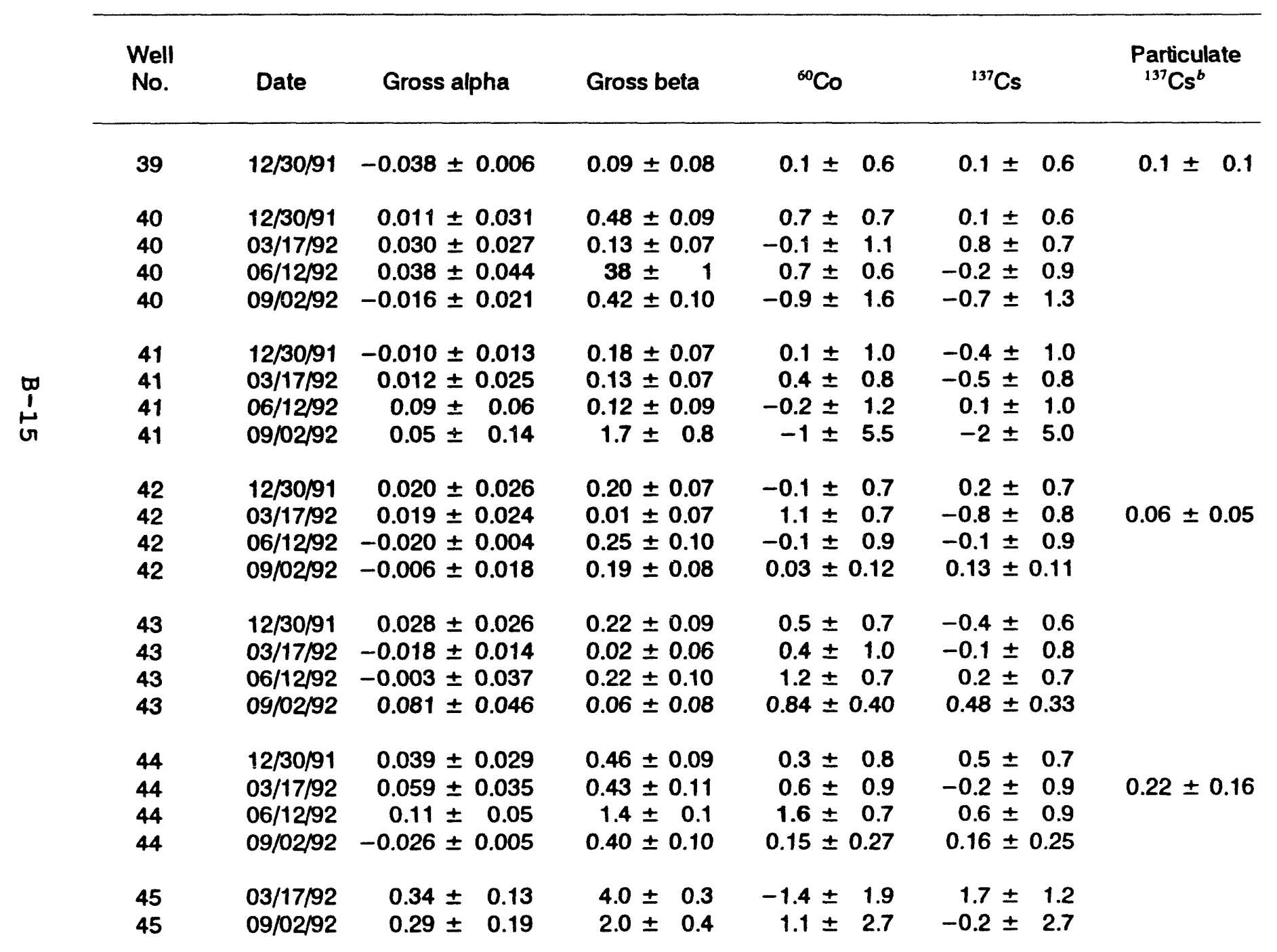


Table B.7 (continued)

\begin{tabular}{|c|c|c|c|c|c|c|c|c|}
\hline $\begin{array}{l}\text { Well } \\
\text { No. }\end{array}$ & Date & Gross alpha & Gross beta & ${ }^{60} \mathrm{Co}$ & & ${ }^{137} \mathrm{Cs}$ & & $\begin{array}{l}\text { Particulate } \\
{ }^{137} \mathrm{Cs}^{b}\end{array}$ \\
\hline 46 & $12 / 30 / 91$ & $0.037 \pm 0.033$ & $0.27 \pm 0.08$ & $0.6 \pm$ & 0.6 & $0.2 \pm$ & 0.6 & \\
\hline 46 & $03 / 17 / 92$ & $0.017 \pm 0.025$ & $0.10 \pm 0.07$ & $0.4 \pm$ & 0.9 & $1.0 \pm$ & 0.7 & \\
\hline 46 & $06 / 12 / 92$ & $0.038 \pm 0.031$ & $0.12 \pm 0.06$ & $-0.1 \pm$ & 0.7 & $-0.1 \pm$ & 0.7 & \\
\hline 46 & $09 / 02 / 92$ & $-0.044 \pm 0.037$ & $0.21 \pm 0.15$ & $0.8 \pm$ & 1.2 & $0.4 \div$ & 1.1 & \\
\hline 47 & $12 / 30 / 91$ & $0.016 \pm 0.046$ & $3.1 \pm 0.3$ & $-0.1 \pm$ & 1.7 & $0.4 \pm$ & 1.4 & \\
\hline
\end{tabular}

- All data are in Becquerel per liter, mean \pm standard error. Boldface indicates value exceeds action level.

${ }^{b}$ Results below detectable activity of about 1 Becquerel per liter except when reported.

to Average of duplicate counts. 
Table B.8. FY 1992 radionuclide data for water collected from wells next to high-range wells, asbestos silos, and fissile wells*

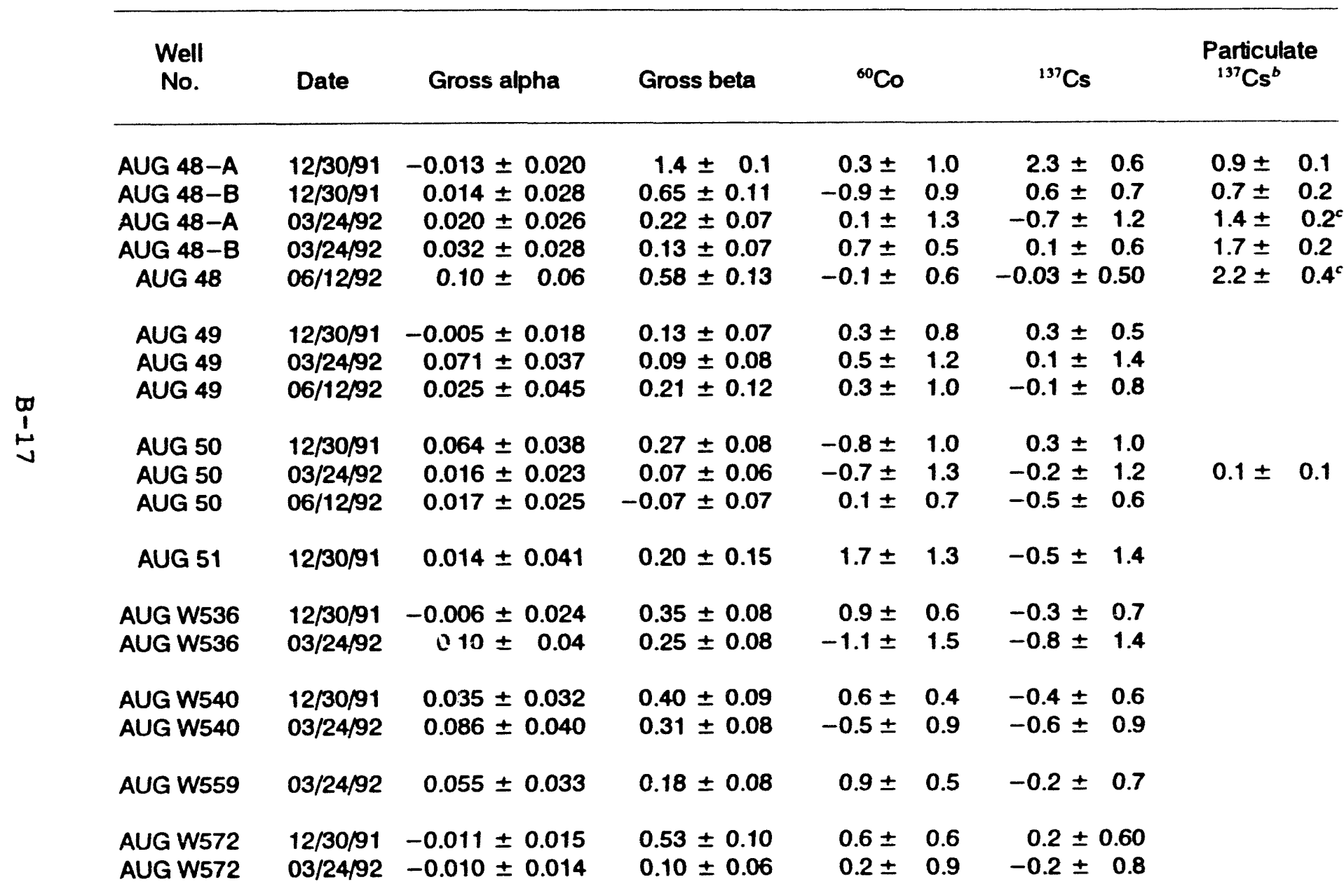


Table B.8 (continued)

\begin{tabular}{|c|c|c|c|c|c|c|}
\hline $\begin{array}{l}\text { Well } \\
\text { No. }\end{array}$ & Date & Gross alpha & Gross beta & ${ }^{60} \mathrm{Co}$ & ${ }^{137} \mathrm{Cs}$ & $\begin{array}{l}\text { Particulate } \\
{ }^{137} \mathrm{Cs}^{b}\end{array}$ \\
\hline $\begin{array}{l}\text { C520 } \\
\text { C520 } \\
\text { C520 } \\
\text { C520 }\end{array}$ & $\begin{array}{l}12 / 30 / 91 \\
03 / 24 / 92 \\
06 / 12 / 92 \\
09 / 03 / 92\end{array}$ & $\begin{array}{r}0.035 \pm 0.025 \\
0.000 \pm 0.023 \\
0.003 \pm 0.020 \\
-0.02 \pm 0.05\end{array}$ & $\begin{array}{l}0.16 \pm 0.07 \\
0.22 \pm 0.09 \\
0.16 \pm 0.07 \\
0.28 \pm 0.18\end{array}$ & $\begin{aligned} 0.9 & \pm 0.6 \\
0.38 & \pm 0.44 \\
0.1 & \pm 1.5 \\
-0.2 & \pm 1.7\end{aligned}$ & $\begin{array}{l}0.2 \pm 0.5 \\
0.3 \pm 0.7 \\
1.0 \pm 1.5 \\
0.6 \pm 1.2\end{array}$ & $0.2 \pm 0.1$ \\
\hline $\begin{array}{l}\text { C595 } \\
\text { C595 } \\
\text { C595 } \\
\text { C595 }\end{array}$ & $\begin{array}{l}12 / 30 / 91 \\
03 / 24 / 92 \\
06 / 12 / 92 \\
09 / 03 / 92\end{array}$ & $\begin{array}{r}0.068 \pm 0.035 \\
0.020 \pm 0.026 \\
0.069 \pm 0.040 \\
0.04 \pm 0.06\end{array}$ & $\begin{array}{l}0.18 \pm 0.08 \\
0.51 \pm 0.10 \\
0.48 \pm 0.09 \\
0.15 \pm 0.15\end{array}$ & $\begin{array}{r}-0.3 \pm 1.0 \\
0.9 \pm 1.0 \\
-0.8 \pm 1.7 \\
-0.3 \pm 1.5\end{array}$ & $\begin{array}{r}0.6 \pm 0.8 \\
0.6 \pm 0.7 \\
-0.5 \pm 1.7 \\
0.4 \pm 1.3\end{array}$ & $\begin{aligned} 0.2 & \pm 0.2 \\
0.2 & \pm 0.1^{\mathrm{c}} \\
1.04 & \pm 0.32\end{aligned}$ \\
\hline $\begin{array}{l}\text { FIS } 102 \\
\text { FIS } 102 \\
\text { FIS } 102 \\
\text { FIS } 102\end{array}$ & $\begin{array}{l}12 / 30 / 91 \\
03 / 24 / 92 \\
06 / 12 / 92 \\
09 / 23 / 92\end{array}$ & $\begin{array}{r}-0.018 \pm 0.014 \\
-0.015 \pm 0.012 \\
0.003 \pm 0.020 \\
0.008 \pm 0.024\end{array}$ & $\begin{array}{l}0.52 \pm 0.09 \\
0.20 \pm 0.07 \\
0.34 \pm 0.07 \\
0.36 \pm 0.08\end{array}$ & $\begin{array}{r}0.1 \pm 0.6 \\
0.8 \pm 0.9 \\
1.0 \pm 0.6 \\
0.12 \pm 0.08\end{array}$ & $\begin{array}{r}0.20 \pm 0.48 \\
-1.6 \pm 1.5 \\
0.2 \pm 0.7 \\
0.03 \pm 0.08\end{array}$ & $0.08 \pm 0.02$ \\
\hline $\begin{array}{l}\text { FIS? } \\
\text { FIS? } \\
\text { FIS? } \\
\text { FIS? }\end{array}$ & $\begin{array}{l}12 / 30 / 91 \\
03 / 24 / 92 \\
06 / 12 / 92 \\
09 / 03 / 92\end{array}$ & $\begin{array}{r}0.090 \pm 0.038 \\
0.000 \pm 0.021 \\
0.028 \pm 0.026 \\
0.22 \pm 0.09\end{array}$ & $\begin{array}{l}0.15 \pm 0.07 \\
0.13 \pm 0.07 \\
0.16 \pm 0.07 \\
0.57 \pm 0.19\end{array}$ & $\begin{aligned} 0.67 & \pm 0.47 \\
-1.1 & \pm 1.7 \\
1.0 & \pm 1.1 \\
0.20 & \pm 0.09\end{aligned}$ & $\begin{array}{rr}0.74 & \pm 0.43 \\
0.2 \pm 1.1 & \pm 1.2 \\
0.1 \pm & \pm 1.2 \\
0.06 & \pm 0.10\end{array}$ & $\begin{array}{r}0.2 \pm \quad 0.1 \\
0.14 \pm 0.09 \\
0.07 \pm 0.03^{c}\end{array}$ \\
\hline
\end{tabular}

- All data are in Becquerel per liter, mean \pm standard error.

b Results below detectable activity of about 1 Becquerel per liter except when reported.

${ }^{c}$ Average of duplicate counts. 
Table B.9. Radionuclide concentrations in SWSA 5 North wells from November 1989 through July $1992^{*}$

\begin{tabular}{|c|c|c|c|c|c|c|c|c|c|c|}
\hline $\begin{array}{l}\text { Sample } \\
\text { date }\end{array}$ & Gross alpha & ${ }^{241} \mathrm{Am}$ & & ${ }^{244} \mathrm{Cm}$ & & Gross be & etab & ${ }^{\infty} \mathrm{Co}$ & ${ }^{137} \mathrm{Cs}$ & Tritium \\
\hline \multicolumn{11}{|c|}{ Well 513} \\
\hline $\begin{array}{l}29 \text { Nov } 89 \\
27 \text { Mar } 90^{c} \\
18 \text { Jun } 90^{c} \\
13 \text { Aug } 90\end{array}$ & $\begin{array}{r}0.068 \pm 0.034 \\
0.05 \pm 0.04 \\
0.012 \pm 0.02 \\
-0.12 \pm 0.03\end{array}$ & & & & & $\begin{array}{r}0.19 \pm \\
0.14 \pm \\
0.09 \pm \\
0.1 \pm\end{array}$ & $\begin{array}{r}0.06 \\
0.05 \\
0.04 \\
0.8\end{array}$ & $\begin{aligned} 0.4 & \pm 1.7 \\
& <0.35 \\
& <0.55\end{aligned}$ & $\begin{array}{l}0.7 \pm 1.9 \\
<0.35 \\
<0.55\end{array}$ & $60 \pm 17.5$ \\
\hline $\begin{array}{l}06 \text { Dec } 90 \\
22 \text { Mar } 91 \\
04 \text { Sep } 91\end{array}$ & $\begin{aligned} 0.02 & \pm 0.02 \\
0.17 & \pm 0.05 \\
-0.029 & \pm 0.001\end{aligned}$ & $\begin{array}{l}0.003 \pm \\
0.002 \pm\end{array}$ & $\begin{array}{l}0.07 \\
0.01\end{array}$ & $\begin{array}{l}-0.004 \pm \\
-0.017 \pm\end{array}$ & $\begin{array}{l}0.002 \\
0.009\end{array}$ & $\begin{array}{l}0.01 \pm \\
0.54 \pm \\
0.13 \pm\end{array}$ & $\begin{array}{l}0.06 \\
0.095 \\
0.095\end{array}$ & $\begin{array}{c}-0.08 \pm 0.115 \\
<0.1 \\
-0.3 \pm 0.55\end{array}$ & $\begin{array}{c}-0.08 \pm 0.095 \\
<0.1 \\
-0.4 \pm 0.55\end{array}$ & $\begin{array}{l}25 \pm 17.5 \\
45 \pm 17 \\
43 \pm 20.5\end{array}$ \\
\hline $\begin{array}{l}16 \text { Dec } 91 \\
09 \text { Mar } 92 \\
24 \text { Jun } 92\end{array}$ & $\begin{array}{l}0.068 \pm 0.049 \\
0.026 \pm 0.023 \\
0.011 \pm 0.04\end{array}$ & $\begin{array}{r}0.008 \pm \\
-0.002 \pm\end{array}$ & $\begin{array}{l}0.008 \\
0.014\end{array}$ & $\begin{array}{l}0.07 \pm \\
0.01 \pm\end{array}$ & $\begin{array}{l}0.011 \\
0.007\end{array}$ & $\begin{aligned}-0.01 & \pm \\
0.2 & \pm \\
0.09 & \pm\end{aligned}$ & $\begin{array}{r}0.1 \\
0.075 \\
0.06\end{array}$ & $\begin{array}{r}0.03 \pm 0.195 \\
-1.5 \pm 1.35 \\
0.05 \pm 0.05\end{array}$ & $\begin{aligned}-0.06 & \pm 0.24 \\
0.7 & \pm 1.05 \\
0.058 & \pm 0.048\end{aligned}$ & $47 \pm 13$ \\
\hline \multicolumn{11}{|c|}{ Well 514} \\
\hline $\begin{array}{l}29 \text { Nov } 89 \\
22 \text { Mar } 90^{c} \\
14 \text { Jun } 90^{c} \\
29 \text { Aug } 90\end{array}$ & $\begin{aligned} 0.053 & \pm 0.031 \\
0.01 & \pm 0.02 \\
0.005 & \pm 0.02 \\
0.02 & \pm 0.22\end{aligned}$ & & & & & $\begin{aligned} 0.26 \pm \\
0.12 \pm \\
0.20 \pm \\
0.4 \pm\end{aligned}$ & $\begin{array}{r}0.065 \\
0.04 \\
0.05 \\
0.85\end{array}$ & $\begin{array}{c}-4 \pm 3.75 \\
<0.35 \\
<0.55\end{array}$ & $\begin{aligned}-1.4 & \pm 2.3 \\
& <0.35 \\
& <0.55\end{aligned}$ & $66 \pm 17.5$ \\
\hline 15 Nov 90 & $0.035 \pm 0.036$ & & & & & $0.04 \pm$ & 0.105 & $0.06 \pm 0.155$ & $0.12 \pm 0.125$ & $33 \pm 17$ \\
\hline $\begin{array}{l}15 \text { Mar } 91 \\
23 \text { Aug } 91\end{array}$ & $\begin{array}{r}0.032 \pm 0.023 \\
-0.011 \pm 0.024\end{array}$ & $\begin{array}{r}0.004 \pm \\
-0.06 \pm\end{array}$ & $\begin{array}{l}0.002 \\
0.065\end{array}$ & $\begin{array}{r}-0.005 \pm \\
-0.18 \pm\end{array}$ & $\begin{array}{l}0.002 \\
0.045\end{array}$ & $\begin{array}{r}0.27 \pm \\
-0.041 \pm\end{array}$ & $\begin{array}{r}0.07 \\
0.078\end{array}$ & $\begin{array}{l}<0.1 \\
0.6 \pm 0.75\end{array}$ & $\begin{array}{r}0.07 \pm 0.03 \\
0.3 \pm 0.8\end{array}$ & $\begin{array}{l}49 \pm 17 \\
63 \pm 20.5\end{array}$ \\
\hline $\begin{array}{l}06 \text { Dec } 91 \\
27 \text { Feb } 92 \\
28 \text { May } 92\end{array}$ & $\begin{array}{r}0.12 \pm 0.06 \\
0.029 \pm 0.030 \\
0.022 \pm 0.038\end{array}$ & $0.001 \pm$ & 0.06 & $\begin{array}{c}0.000 \pm \\
-0.002 \pm\end{array}$ & 0.003 & $\begin{array}{r}0.28 \pm \\
0.00 \pm \\
-0.08 \pm\end{array}$ & $\begin{array}{l}0.125 \\
0.065 \\
0.085\end{array}$ & $\begin{array}{rlr}-0.5 & \pm & 0.9 \\
-0.2 & \pm & 0.9 \\
0.27 & \pm 0.135\end{array}$ & $\begin{aligned}-0.5 & \pm 0.9 \\
0.1 & \pm 0.8 \\
0.06 & \pm 0.165\end{aligned}$ & $31 \pm 12.5$ \\
\hline
\end{tabular}


Table B.9 (continued)

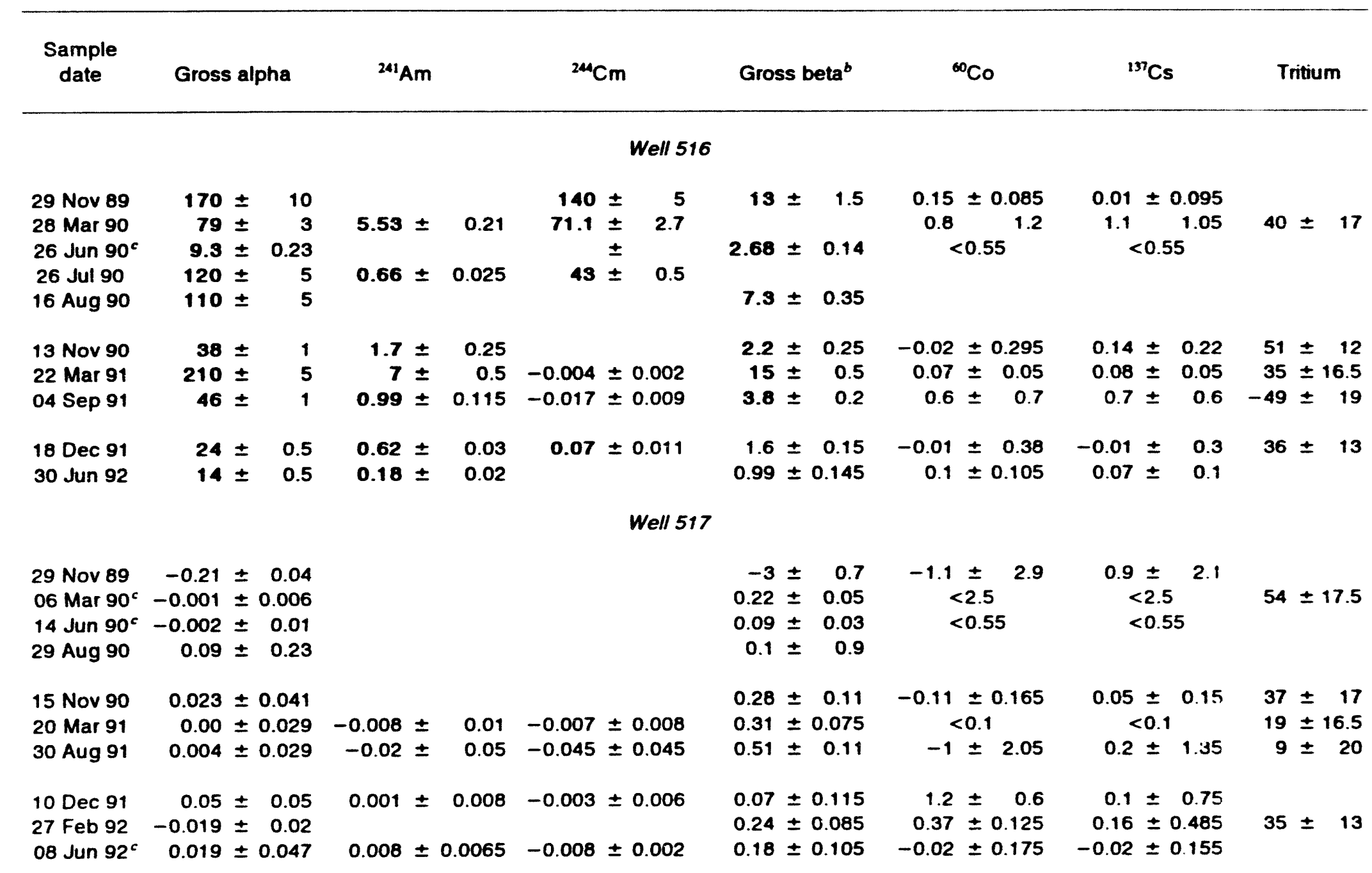




\section{Table B.9 (continued)}

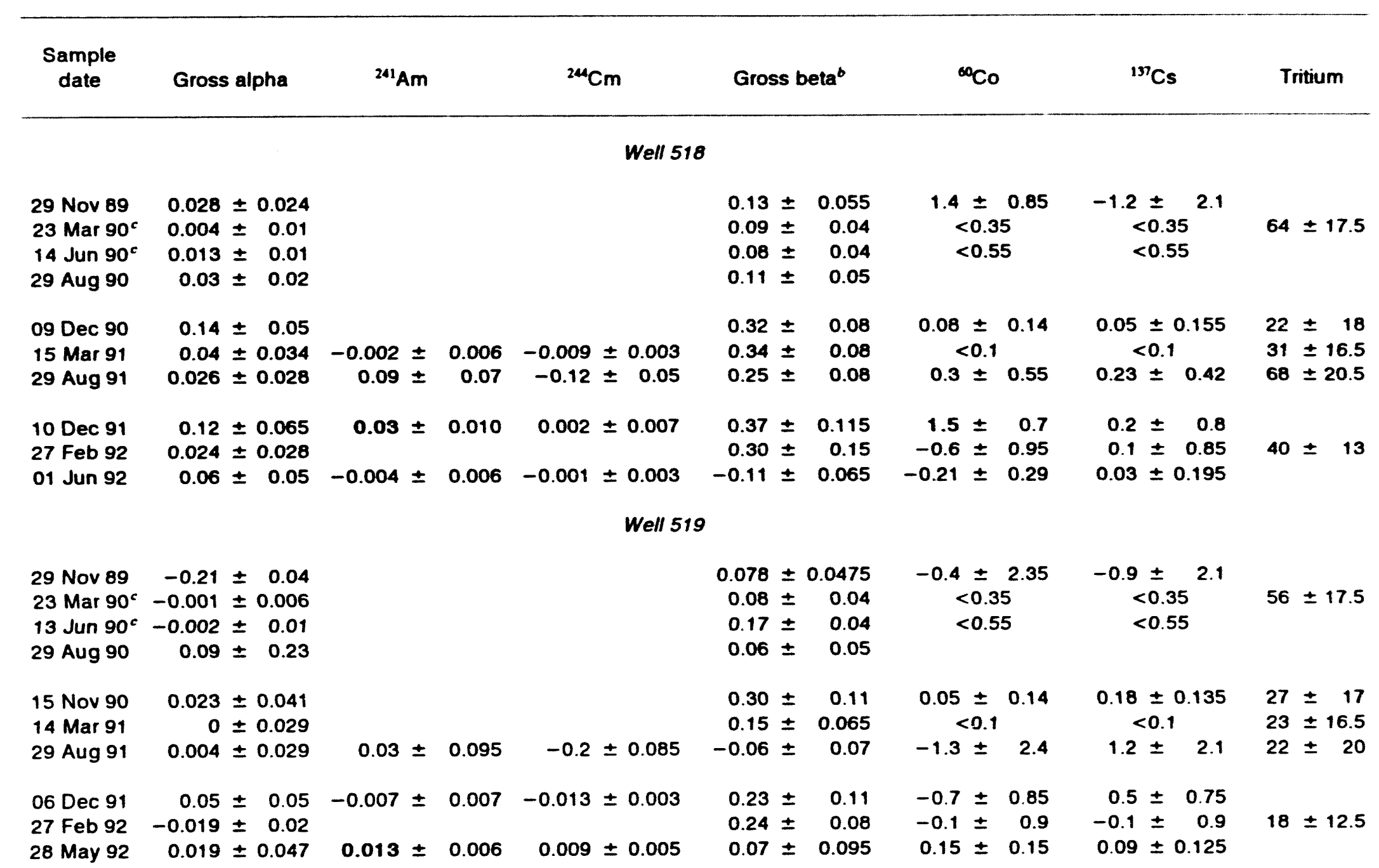


Table B.9 (continued)

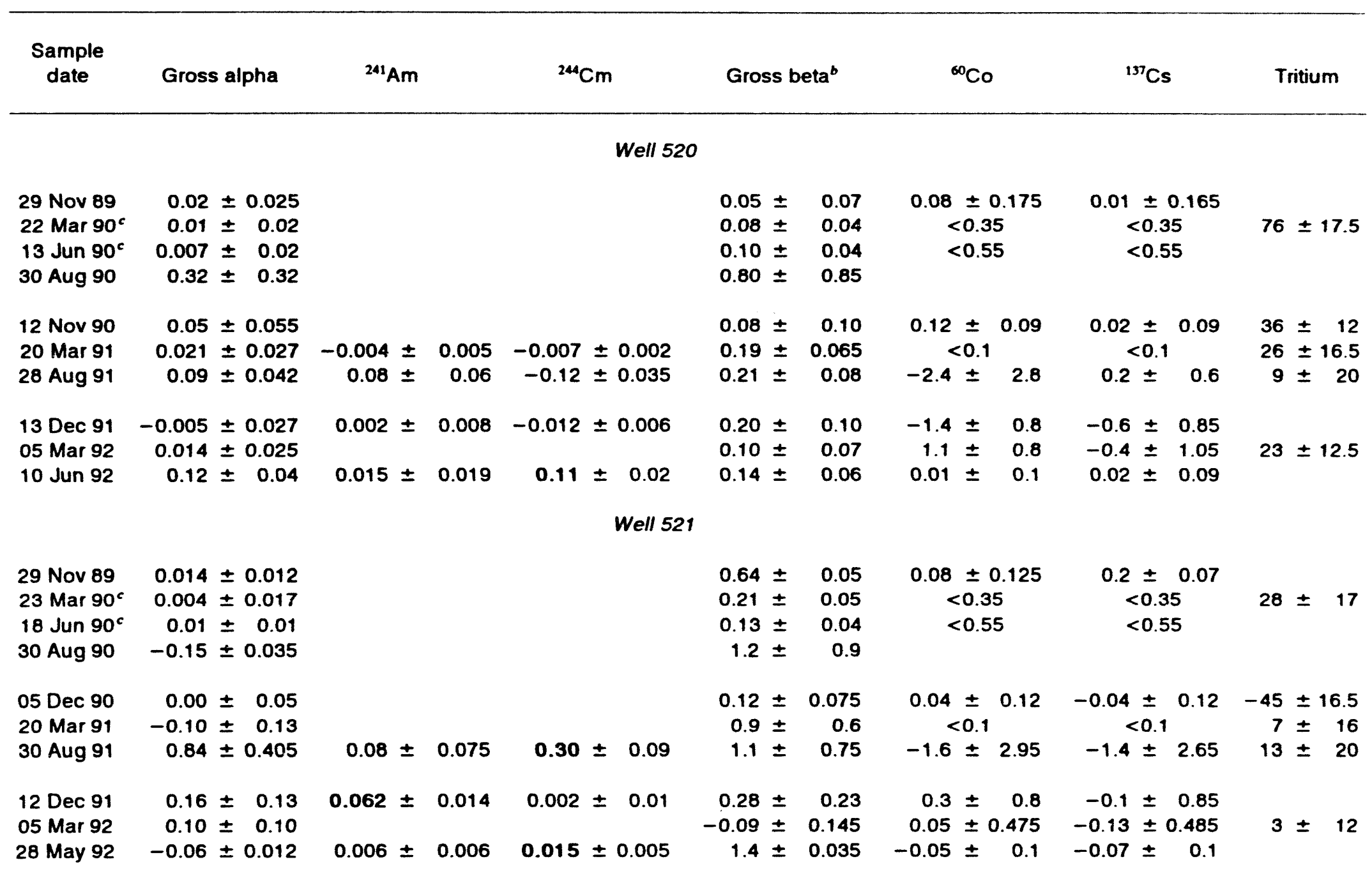


Toble B.9 (continued)

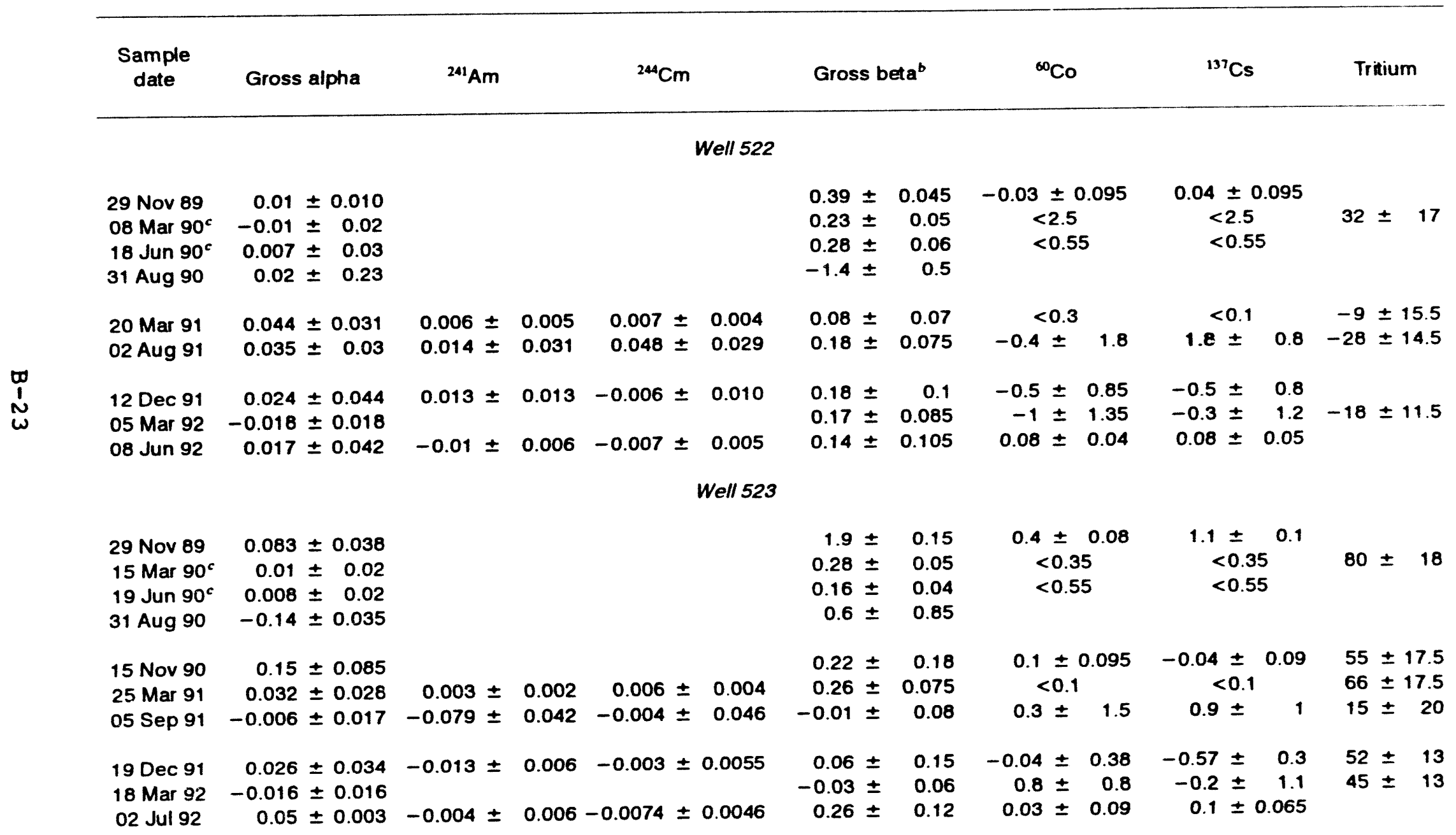


Table B.9 (continued)

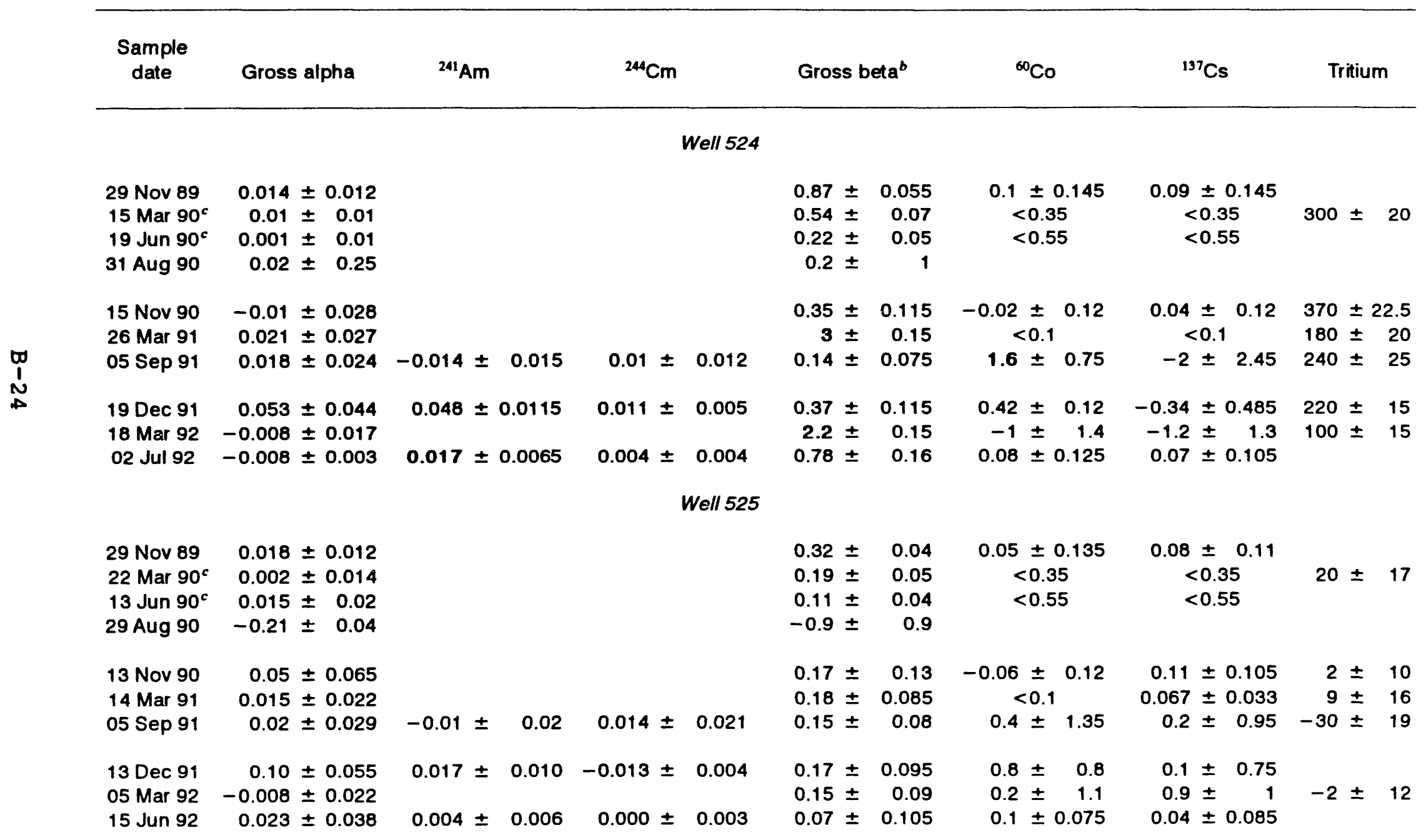


Table B.9 (continued)

\begin{tabular}{|c|c|c|c|c|c|c|c|c|c|c|}
\hline $\begin{array}{l}\text { Sample } \\
\text { date }\end{array}$ & Gross alpha & ${ }^{241} \mathrm{Am}$ & & ${ }^{244} \mathrm{Cm}$ & & \multicolumn{2}{|c|}{ Gross beta ${ }^{b}$} & ${ }^{60} \mathrm{Co}$ & ${ }^{137} \mathrm{Cs}$ & Tritium \\
\hline \multicolumn{11}{|c|}{ Well 708} \\
\hline $\begin{array}{l}06 \text { Dec } 90 \\
22 \text { Mar } 91 \\
04 \text { Sep } 91\end{array}$ & $\begin{aligned} 0.01 & \pm 0.02 \\
0.022 & \pm 0.021 \\
-0.043 & \pm 0.026\end{aligned}$ & $\begin{array}{r}-0.002 \pm \\
0.005 \pm\end{array}$ & $\begin{array}{l}0.003 \\
0.003\end{array}$ & $\begin{array}{r}-0.002 \pm \\
0.00 \pm\end{array}$ & $\begin{array}{r}0.003 \\
0.05\end{array}$ & $\begin{array}{r}0.1 \pm \\
0.26 \pm \\
0.11 \pm\end{array}$ & $\begin{array}{l}0.06 \\
0.07 \\
0.09\end{array}$ & $\begin{array}{c}0.07 \pm 0.105 \\
<0.1 \\
0.7 \pm 1.05\end{array}$ & $\begin{array}{c}0.15 \pm 0.06 \\
<0.1 \\
0.89 \pm 0.415\end{array}$ & $\begin{array}{r}220 \pm 20 \\
120 \pm 20 \\
-6 \pm 19.5\end{array}$ \\
\hline $\begin{array}{l}16 \text { Dec } 91 \\
11 \text { Mar } 92 \\
24 \text { Jun } 92\end{array}$ & $\begin{aligned} 0.005 & \pm 0.036 \\
-0.014 & \pm 0.004 \\
0.044 & \pm 0.026\end{aligned}$ & $\begin{array}{r}0.01 \pm \\
0.012 \pm\end{array}$ & $\begin{array}{l}0.006 \\
0.009\end{array}$ & $\begin{array}{r}0.15 \pm \\
0.075 \pm\end{array}$ & $\begin{array}{l}0.015 \\
0.013\end{array}$ & $\begin{array}{l}0.26 \pm \\
0.01 \pm \\
0.15 \pm\end{array}$ & $\begin{array}{r}0.115 \\
0.07 \\
0.06\end{array}$ & $\begin{array}{r}0.09 \pm 0.38 \\
0.1 \pm 0.8 \\
-0.01 \pm 0.105\end{array}$ & $\begin{array}{r}0.15 \pm 0.35 \\
0.2 \pm 0.105 \\
0.03 \pm 0.08\end{array}$ & $56 \pm 13.5$ \\
\hline \multicolumn{11}{|c|}{ Well 715} \\
\hline $\begin{array}{l}15 \text { Nov } 90 \\
15 \text { Mar } 91 \\
29 \text { Aug } 91\end{array}$ & $\begin{array}{l}0.026 \pm 0.034 \\
0.076 \pm 0.039 \\
0.029 \pm 0.034\end{array}$ & $\begin{array}{l}0.008 \pm \\
0.002 \pm\end{array}$ & $\begin{array}{l}0.009 \\
0.002\end{array}$ & $\begin{array}{r}-0.004 \pm \\
0.004 \pm\end{array}$ & $\begin{array}{l}0.006 \\
0.003\end{array}$ & $\begin{array}{r}0.6 \pm \\
0.34 \pm \\
0.19 \pm\end{array}$ & $\begin{array}{r}0.12 \\
0.075 \\
0.075\end{array}$ & $\begin{array}{c}-0.09 \pm 0.17 \\
<0.1 \\
-2 \pm 2.4\end{array}$ & $\begin{array}{c}-0.03 \pm 0.14 \\
<0.1 \\
-0.8 \pm 2.45\end{array}$ & $\begin{array}{l}10 \pm 16.5 \\
42 \pm 16.5 \\
21 \pm 20\end{array}$ \\
\hline $\begin{array}{l}10 \text { Dec } 91 \\
27 \text { Feb } 92 \\
01 \text { Jun } 92\end{array}$ & $\begin{array}{r}0.024 \pm 0.031 \\
0.00 \pm 0.02 \\
0.038 \pm 0.027\end{array}$ & $\begin{array}{l}0.003 \pm \\
0.006 \pm\end{array}$ & 0.011 & $\begin{array}{l}0.003 \pm \\
0.005 \pm\end{array}$ & $\begin{array}{l}0.011 \\
0.005\end{array}$ & $\begin{array}{l}0.37 \pm \\
0.17 \pm \\
0.16 \pm\end{array}$ & $\begin{array}{r}0.11 \\
0.075 \\
0.065\end{array}$ & $\begin{array}{rlr}0.4 & \pm & 0.8 \\
-0.7 & \pm & 1.2 \\
0.17 & \pm 0.105\end{array}$ & $\begin{array}{rlr}0.2 & \pm 0.8 \\
0.6 & \pm \\
-0.17 & \pm 0.145\end{array}$ & $26 \pm 12.5$ \\
\hline
\end{tabular}


Table B.9 (continued)

\begin{tabular}{|c|c|c|c|c|c|c|c|c|c|c|c|c|}
\hline $\begin{array}{c}\text { Sample } \\
\text { date }\end{array}$ & Gross alpha & ${ }^{241} \mathrm{Am}$ & & ${ }^{244} \mathrm{Cm}$ & & \multicolumn{2}{|c|}{ Gross beta ${ }^{b}$} & \multicolumn{2}{|c|}{${ }^{60} \mathrm{Co}$} & \multicolumn{3}{|r|}{ Tritium } \\
\hline \multicolumn{13}{|c|}{ Well 716} \\
\hline $\begin{array}{l}06 \text { Dec } 90 \\
22 \text { Mar } 91\end{array}$ & 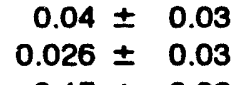 & & & & & $\begin{array}{r}0.27 \pm \\
0.059 \pm\end{array}$ & $\begin{array}{l}0.08 \\
0.01\end{array}$ & $\begin{array}{r}0.11 \pm 0 \\
<0.1\end{array}$ & 0.095 & $\begin{array}{r}0.09 \pm \\
<0.1\end{array}$ & 0.1 & $\begin{array}{l}-30 \pm 17 \\
-20 \pm 15.5\end{array}$ \\
\hline 04 Sep 91 & $0.15 \pm 0.06$ & $0.067 \pm$ & 0.015 & $0.039 \pm$ & 0.012 & $0.83 \pm$ & 0.115 & $0.8 \pm$ & 0.65 & $0.2 \pm$ & 1.35 & $-70 \pm 37$ \\
\hline $\begin{array}{l}16 \text { Dec } 91 \\
09 \text { Mar } 92 \\
24 \text { Jun } 92\end{array}$ & $\begin{array}{r}0.52 \pm 0.36 \\
0.085 \pm 0.048 \\
0.09 \pm 0.065\end{array}$ & $\begin{array}{l}0.01 \pm \\
0.007 \pm\end{array}$ & 0.007 & $0.022 \pm$ & 0.005 & $\begin{array}{l}1.1 \pm \\
0.66 \pm \\
0.28 \pm\end{array}$ & $\begin{array}{r}0.3 \\
0.11 \\
0.115\end{array}$ & $\begin{array}{r}0.5 \pm \\
1.6 \pm \\
0.23 \pm\end{array}$ & $\begin{array}{r}0.7 \\
0.9 \\
0.05\end{array}$ & $\begin{array}{r}-0.2 \pm \\
0.1 \pm \\
0.04 \pm\end{array}$ & $\begin{array}{r}0.8 \\
1.1 \\
0.12\end{array}$ & \\
\hline
\end{tabular}

- All results are in Becquerel/liter, mean \pm standard counting error. Blanks indicate analysis not performed. Samples collected prior to October were acidified but not filtered. Samples collected beginning in October 1991 were filtered prior to acidification. Boldface indicates value exceeds action level.

- Gross beta analysis does not include tritium.

c Gross alpha/beta analyses were performed in Health and Safety Research Division counters after sample preparation in Environmental Sciences Division (ESD). Values for these analyses are typically lower than values from analyses performed in Analytical Chemistry Division. Gamma scans were performed in the ESD counting room. 


\section{Table B.10. Radionuclide concentrations in SWSA 5 North seeps from March 1990 through July 1992*}

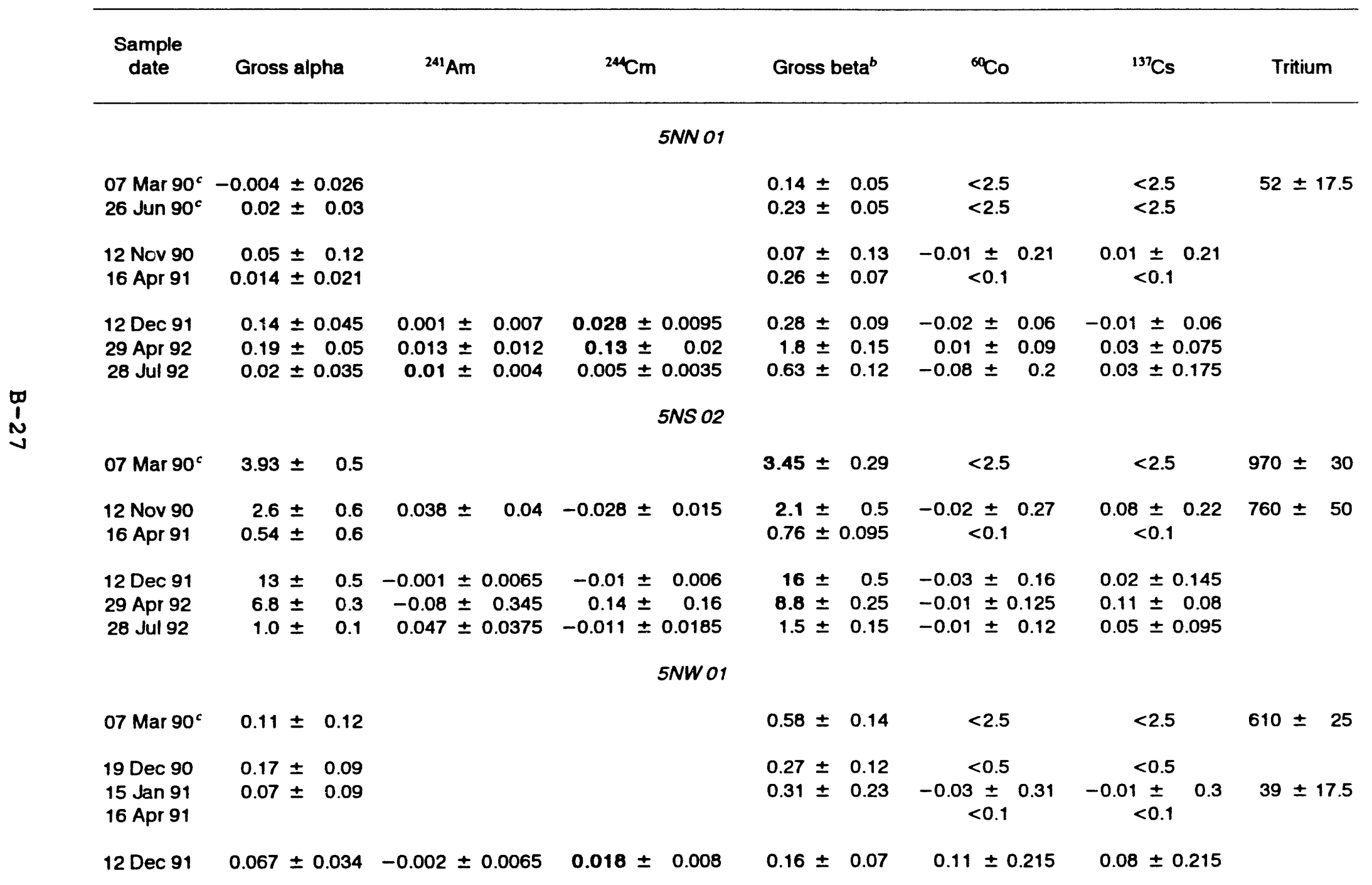


Table B.10 (continued)

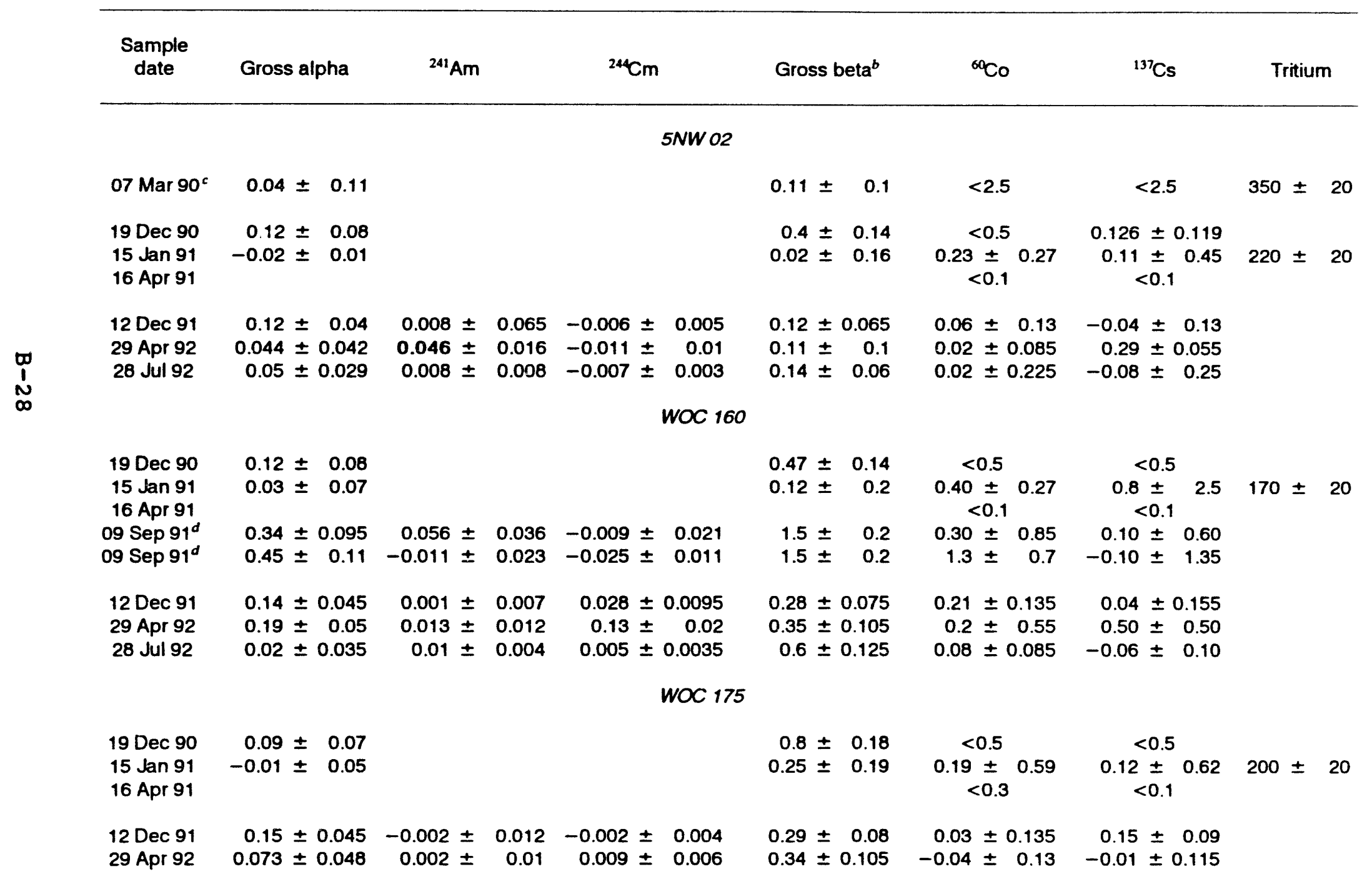


Table B.10 (continued)

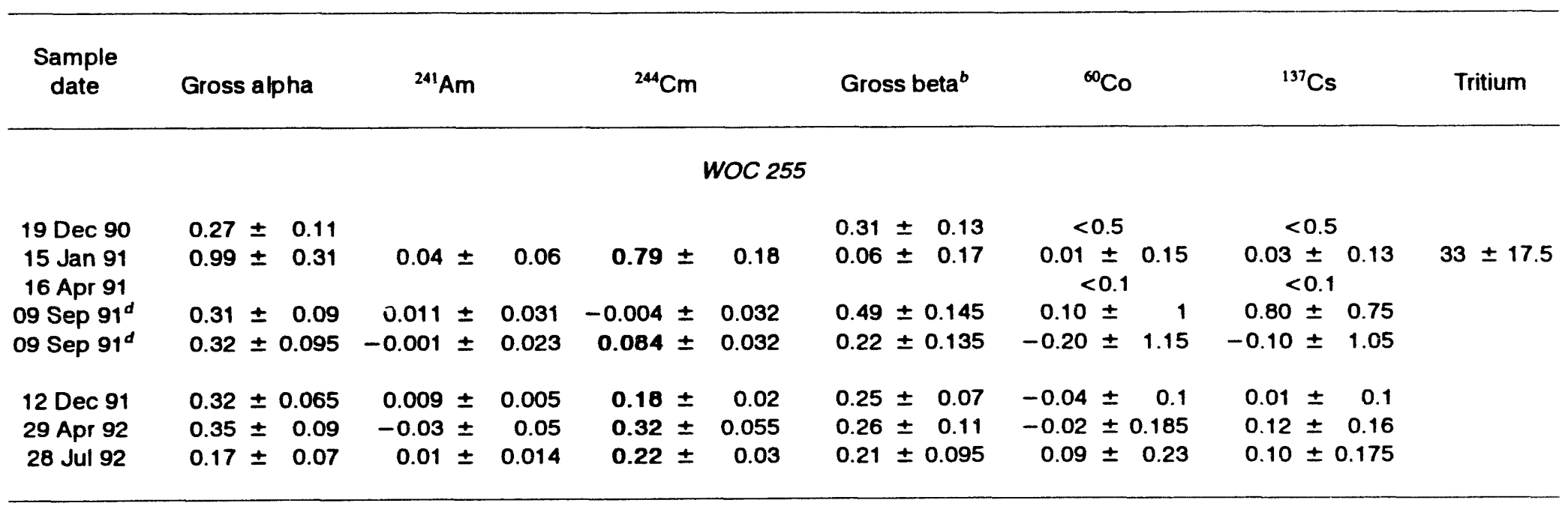

- All results are in Becquerel/liter, mean \pm standard counting error. Blanks indicate analysis not performed. Samples collected prior to October were acidified but not filtered. Samples collected beginning in October 1991 were filtered prior to acidification. Boldface indicates value exceeds action level.

- Gross beta analysis does not include tritium.

c Gross alpha/beta analyses were performed in Health and Safety Research Division counters after sample preparation in Environmental Sciences Division (ESD). Values for these analyses are typically lower than values from analyses performed in Analytical Chemistry Division. Gamma scans were performed in the ESD counting room.

$₫$ Duplicate samples. 


\section{APPENDIX C:}

ASEMP-RELATED FINDINGS OF DOE SURVEILLANCE IN SWSA 5 NORTH 


\section{Internal Correspondence}

MUTTN MAALTTA ENEROY SYSTEMS. INC

April 22, 1992

D. F. Hall

Response to DOE Surveillance of Solld Waste Operations at ORNL

I have reviewed the draft report from DOE on the subject surveillance. Following are responses to the ASEMPI deficiencies noved in section 3.1 .9 of the draft repor.

EOA-22-03-18-B: No gross alpha or beta action levels are used for certain opentional samples.

This deficiency primarily concems operational samples collecred by Soild Waste Operations personnel from sumps in four buildings a SWSA $S$ Narth. It is my undersanding that you will address the deficiencies associated with those sumples. However, the discussion following this deficiency also includes a misinterpretusion by the surveillance team of the ASEMP action levels for SWSA 5 North-specifically the lack of an action level for gross alpha contamination. As discussed in the ASEMP propram plan (ORNLM-1793) and the ASEMP action level repor (ORNLM-1569), no groses alpha action level was established for SWSA S North because we no longer use gross alphe as a screening wool for SWSA 5 North. The gross alpha analysis is not sufficiently sensitive to dewect the presence of transuranic isotopes (Le., $211 \mathrm{Am}$ and $24 \mathrm{Cm}$ ) as concentrations thas are found in some SWSA 5 North samples (e.g., $40.1 \mathrm{Bg} / \mathrm{L}$ ). All ASEMP sumples are now andyzed for $241 \mathrm{Am}$ and $244 \mathrm{Cm}$, and the presence of these isoropes above devection limits is used as a sereen to determine whecher further sction is required.

EQA-92-03-18-D: The logbooks for ground wherer and surface water sampling activities are not formally controlled

The ariginal program plan did not require that field novebooks be formally controlled The current revision of the plan, which was issued in February 1992, includes a requirement for formal control of all technical notebooks. Nowbooks in cument use are officially registered through Laboratory Records and are maintained in scoord ance with ESD and ORNL procedures.

EOA-92-03-18-E: Numerous Groundwater Monitoring Summery Shees did nor include required and essential daca.

See response to EQA-92-03-18-H.

\footnotetext{
I ASEMP - Active Siter Environmental Moniboring Proprem.
} 
EOA.92-03-18-E: Operational monitering wells are not being purged as required

Our purging procedure requires thas most SWSA 5 Narch wells be pumped dry, allowed to recover overnighe and sampled the following day. This deficiency refers to those few wells thus are sufficiendy productive thus they cannot be pumped dry. One to three well volumes should be purged trom these wells, depending upon how long it cules to stabilize the panmesers of tempernare, $\mathrm{pH}$, and conductivity, sampling should occur immediately after purging. For the most recent quareviy sampling, this procedure was not followed by the field technician, and the wells were sampled the day following purging. It is unlikely that this problem will adversely affect the quality of the dan from these wells, but we will now the nonconformunce when reportiog the din.

The trining progrem identified in the response to EQA-92-03-18-H will address this issue. Rourine surveillances by the progenm manager, as identified in the most recent drati of the progonm QA plan, will also be used to ensure thri procedures are followed.

EOA.92-03-18.9: The identification of the sampler is not documented on the groundwater data sheets or the field logbooks.

See response to EQA-92-03-18-H.

EOA-92-03-18.4: The roview system for ASEP [sic] dan is inadequate.

This deficieacy reflects the aunure of the wechnical socebools in use prior to the huest revision of the prognm plan. At the time of the ariginal plan, the ASEMP was viewed as as operational monitoring progenm with little requirement for the rigarous dan coatrol typical of compliance moniwing. To a lage extent, we still view the progrem in thas lighe and the current QA plan, which casries a QA level desigmation of III, reflects that spproach Nevertheless, we recognize the greaser control over the ecquisition and reconding of din is necosenty, and the current proponm plan and the mon recent dreft of the QA phin both adtreas this isve.

A trining progen for all ASEMP stel will be conducted during the thind quaruer of FY 1992. This triming will include all proceduril requiruments of the proporm plen and all appects of the QA plen. In eddition, the the mose receat dint of the QA plen includes sirveillances by the proconon manger of all sumpling sctivitien.

I bope thus these responses adequately address the isnes raised by the surveillance ream. We appreciate the surveillance teem's effors because they belped us identify ares where improvernens is needed. Please call me if you have any questions.

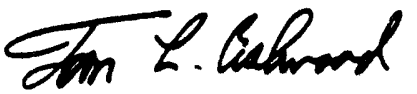

Tom L. Ashwood, Blde. 1505, MS 6036, ORNL (4-7542)

TIAT
ce R. B. Clppp
J. M. Loer
L. E. Robersoa
D. S. Marihall
S. H. Swow
C. M. Marisesy
A. L Thomes
D. S. Wictlife 


\section{INTERNAL DISTRIBUTION}

ORNL $/ M-3183$

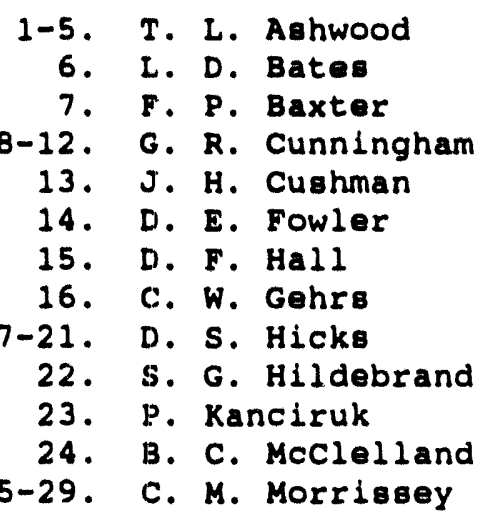

\author{
30. D. E. Reichle \\ 31. T. F. Scanlan \\ 32. F. E. Sharples \\ 33. D. S. Shriner \\ 34. S. H. Stow \\ 35. S. D. Van Hoesen \\ 36. Central Research Library \\ 37-51. ESD Library \\ 52-53. Laboratory Records Dept. \\ 54. Laboratory Records, ORNL-RC \\ 55. ORNL Patent section \\ 56. ORNL Y-12 Technical Library
}

\section{EXTERNAL DISTRIBUTION}

57. R. N. Farvolden, Professor, Department of Earth Sciences, University of Waterloo, Waterloo, Ontario N2L Canada

58. D. W. Freckman, Director, College of Natural Resources, 101 Natural Resources Building, Colorado State University, Fort Collins, Co 80523

59. R. C. Harriss, Institute for the study of Earth, Oceans, and Space, Science and $E^{-}$.neering Research Building, University of New Hampshire, Durham, NH 038. 4

60. G. Y. Jordy, Director, Office of Program Analysis, office of Energy Research, ER-30, G-226, U.S. Department of Energy, Washington, DC 20545

61. A. Patrinos, Director, Environmental Sciences Division, office of Health and Environmental Research, ER-74, U.S. Department of Energy, Washington, DC 20585

62. L. I. Radcliffe, Director, Waste Management and Technology Development Division, U.S. Department of Energy, Oak Ridge Operations office, P.O. Box 2001, Oak Ridge, TN 37831-8620

63. L. C. M. Roddye, Program Manager, Waste Management and Technology Development Division, U.S. Department of Energy, Oak Ridge Operations office, P.O. Box 2001, Oak Ridge, TN 37831-8620

64. F. J. Wobber, Environmental Sciences Division, Office of Health and Environmental Research, ER-74, U.S. Department of Energy, Washington, DC 20585

65. Office of Assistant Manager for Energy Research and Development, U.S. Department of Energy Oak Ridge Operations, P.O. Box 2001, Oak Ridge, TN $37831-3600$

66-67. Office of Scientific and Technical Information, P.0. Box 62, Oak Ridge, TN 37831 

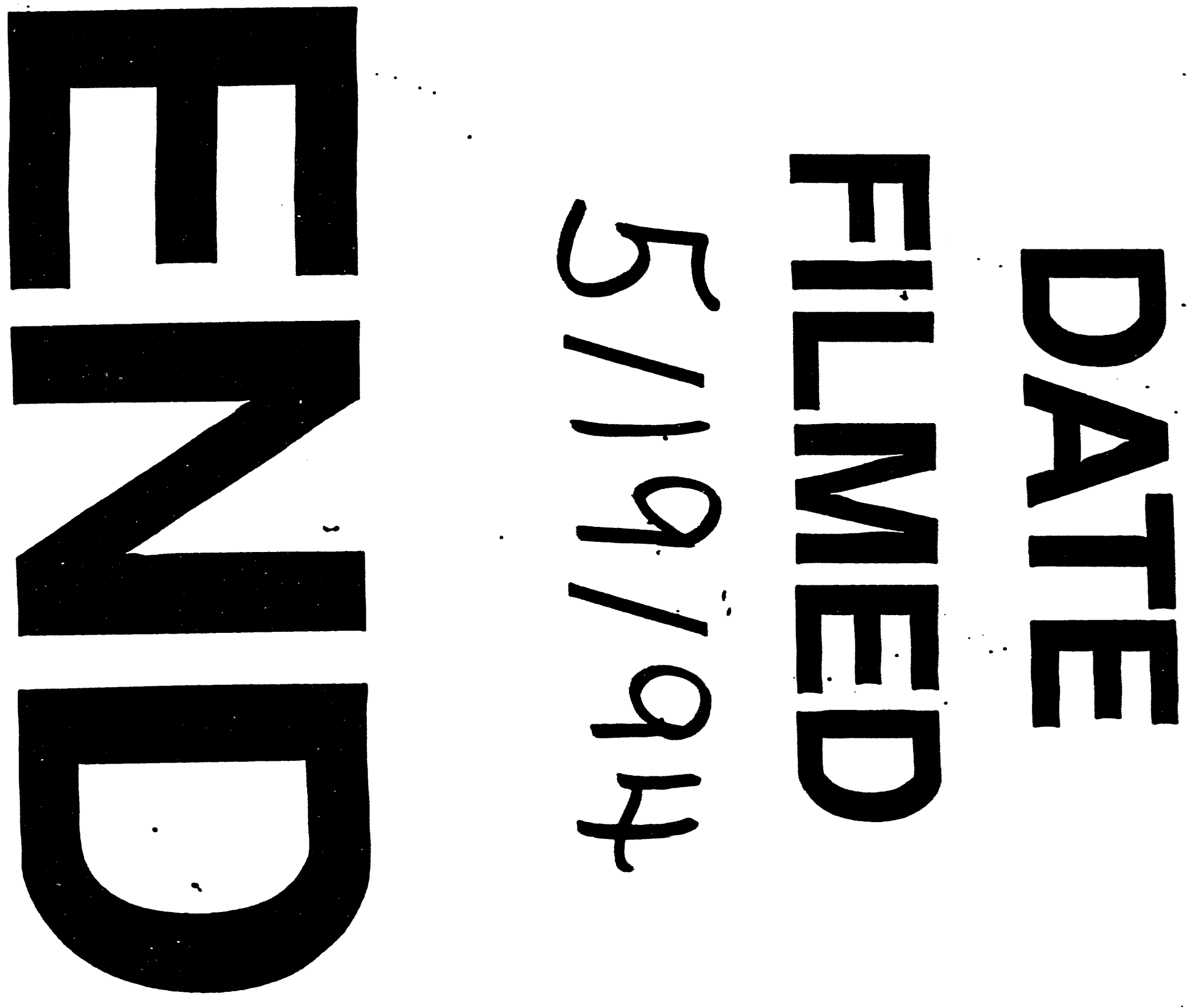
